\title{
The Modulatory Effects of Salbutamol in the Basolateral Nucleus of the Amygdala on Learning and Memory Impairments Induced by Foot-shock Stress in the Male Rat \\ Gholam Hossein Meftahi', Zahra Bahari ${ }^{2}$ Mohammad Reza Afarinesh ${ }^{3}$, Boshra Hatef ${ }^{4}$
}

1. Associate Professor, Neuroscience Research Center, Baqiyatallah University of Medical Sciences, Tehran, Iran., (Corresponding Author), Email: hossein.meftahi@bmsu.ac.ir, meftahi208@yahoo.com, Tel; 021-87554148, ORCID ID: 0000-0003-0665-186X.

2. Assistant Professor, Department of Physiology and Medical Physics, Faculty of Medicine, Baqiyatallah University of Medical Sciences, Tehran, Iran. ORCID ID: 0000-0003-3205-1235.

3. Assistant Professor, Neuroscience Research Center, Institute of Neuropharmacology, Kerman University of Medical Sciences, Kerman, Iran. ORCID ID: 0000-0002-5122-9900.

4. Assistant Professor, Neuroscience Research Center, Baqiyatallah University of Medical Sciences, Tehran, Iran. ORCID ID: 0000-0002-2638-3463.

ABSTRACT

Background and Aim: Beta-adrenergic receptors in the basolateral nucleus of the amygdala (BLA) have been associated with stress, learning, and memory. In this study, we tested the effects of intra-BLA microinfusions of the $\beta_{2}$-adrenergic receptor agonist, salbutamol, on spatial, passive avoidance memory and long-term potentiation (LTP) in the CA1 region of the hippocampus in response to stress.

Materials and Methods: Forty male rats were randomly divided into five groups ( $\mathrm{n}=8 / \mathrm{per}$ group): control, sham, stress, salbutamol+control, and salbutamol+stress. Bilateral cannulation was performed in the BLA, by using stereotaxic apparatus. Then, the rats were transferred to the communication box and foot-shock stress induction continued for four consecutive days. Five minutes before stress, salbutamol $(4 \mu \mathrm{l} / \mathrm{side})$ was injected bilaterally into the BLA. Barnes maze and shuttle box were examined for spatial and passive avoidance memory, respectively. The field potential recording was also used to investigate LTP in the CA1 neurons of the hippocampus.

Results: The results of the passive avoidance test showed that bilateral injection of salbutamol in the BLA five minutes before stress increased step-through latency time significantly compared to the stress group. Barnes maze results showed that intra-BLA microinfusions of salbutamol before stress, reduced the latency time, the number of errors, and the distance traveling to achieve the target hole compared to the stress group. Field potential recording revealed that salbutamol injection before stress decreased the population spike amplitude significantly and caused fEPSP slope 60 minutes after high-frequency stimulation compared to the stress groups.

Conclusion: It seems that the salbutamol in the BLA can improve memory deficits induced by stress.

Keywords: Barnes maze, $\beta_{2}$-adrenergic receptors, Foot-shock Stress, Passive Avoidance Test, Salbutamol

Received: June 19, 2019

Accepted: July 9, 2019

How to cite the article: Gholam Hossein Meftahi, Zahra Bahari Mohammad Reza Afarinesh, Boshra Hatef. The Modulatory Effects of Salbutamol in the Basolateral Nucleus of the Amygdala on Learning and Memory Impairments Induced by Foot-shock Stress in the Male Rat. SJKU. 2021;26(1):53-71.

Copyright (C) 2018 the Author (s). Published by Kurdistan University of Medical Sciences. This is an open access article distributed under the terms of the Creative Commons Attribution-Non Commercial License 4.0 (CCBYNC), where it is permissible to download, share, remix, transform, and buildup the work provided it is properly cited. The work cannot be used commercially without permission from the journal 


\section{اثرات تعديلى سالبوتامول در هسته قاعده اى-جانبى آميكدال بر اختلالات حافظه و يادتيرى ناشى

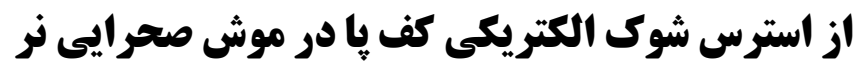

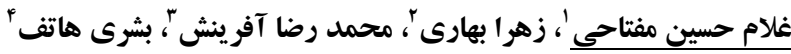

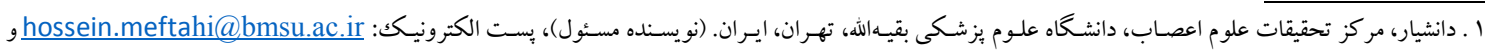

meftahi208@yahoo.com

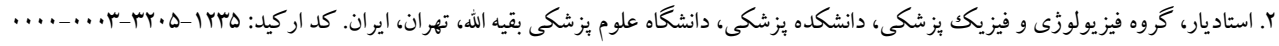

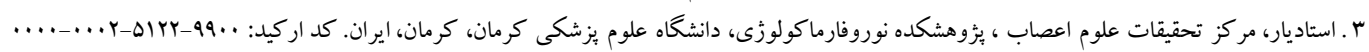

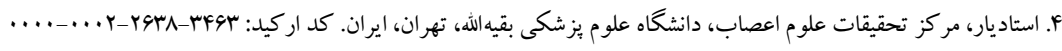

جִكيده

زمينه و هدف: رسـيتورهاى بتـا-آدرنرزيـك در هسته قاعـدهاى -جـانبى آميكـدال در ارتبـاط بـا اسـترس و حافظه و يـاد كيرى مىباشند. در مطالعه حاضر اثرات تزريق آكونيست رسيتورهاى بتاب-آدرنرزيك، سالبوتامول، در هسته قاعدهاى -جـانبى آميخـدال به دنبال استرس بر حافظه فضايى، احترازى غيرفعال و تقويت طولانى مدت سينايسى در نورونهاى CA1 هيبو كمٍ مورد بررسى قرار گرفت.

مواد و روش ها: جهل سر موش صحرايى نر بطور تصادفى به ينج گروه تقسيم شدند ( n=N در هر گروه): كنترل، شم، استرس، سالبو تامول+كنترل و سالبو تامول+اسـترس. در دسـتخاه اسـترئوتاكس كـانول گَذارى بصـورت دوطرفه در هسـته قاعـدهاى -جـانبى آميكدال انجام شد. سيس حيوانات در دستگاه جعبه ارتباطى قرار داده شدند و به مدت جهار روز تحت استرس شوكى الكتريكى

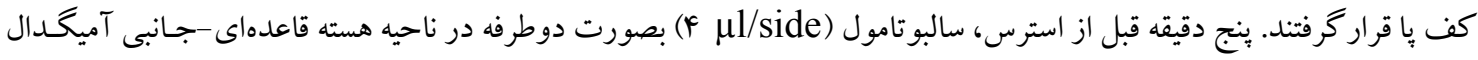
تزريق گرديد. ماز بارنز و شاتل باكس به ترتيب براى بررسى رفتارهاى حافظه فضايى و احترازى غيرفعال مورد بررسى قرارگرفت.

$$
\text { جهت بررسى تقويت طولانى مدت در نورونهاى CA1 هييو كمي از ثبت پِتانسيل ميدانى استفاده كرديد. }
$$

يافته ها: نتايج حافظه احترازى غيرفعال نشان داد كه تزريق دوطرفه سالبوتامول در ناحيه هسته قاعدهاى-جانبى آميگدال ينج دقيقـه قبل از استرس افزايش معنىدارى ر رادر زمان تاخير نسبت به گروه استرس نشان داد. تزريق سـالبو تامول در هسته قاعـدهاى -جـانبى آميكدال قبل از استرس زمان رسيدن، مسافت و تعداد خطاها در رسيدن به سوراخ هدف را در تست بارنز بطور معنىدارى نسبت به گُروه استرس كاهش داد. نتايج ثبت يتانسيل ميدانى نشان داد كه تزريق سـالبوتامول قبـل از اسـترس، كـاهش معنـادارى در دامنهـ

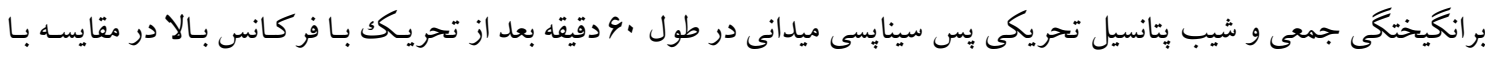

$$
\text { كروه استرس ايجاد مى كند. }
$$

نتيجه كيرى: بنظر مىرسد كه سالبو تامول در هسته قاعدهاى-جانبى آميخدال مىتواند نقايص حافظه را كه به دنبال استرس ايجاد شده بود را بهبود بخشد. وازه هاى كليدى: ماز بارنز، گيرنده هاى 2-آدرنرزيكك، استرس شوكى كف يا، تست احترازى غيرفعال، سالبوتامول

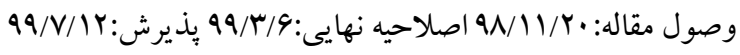


از مغز كه در حافظه و ياد گيرى نقـش دارد) نيـز در اسـترس

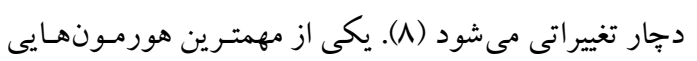
كه در زمان استرس آزاد مى شـود نور آدرنـالين اسـت. نشـان داده شده است كه نور آدرنالينى كه در زمان هيجانات ترشح مىشود در ذخيـره حافظه بلنــد مـــت نقـش دارد و اسـترس

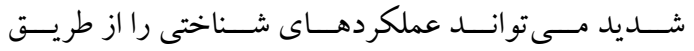
مكانيسمهـاى آدرنرزيـك مختـل كنــ (9). ناحيـه BLA و هيبو كمٍ مقادير قابل توجهى وروديهاى نور آدرنرزيكك از لو كوس سرولئوس دريافت مى كنند و ميزان نور آدرنرزيكك در BLA در زمان اسـترس بـه ميـزان قابـل تـوجهى افزايش

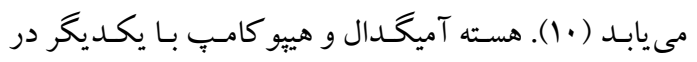

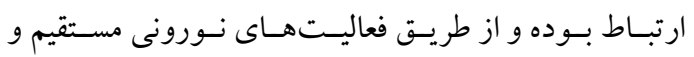
غيرمستقيم بر جنبه هاى مختلف حافظه و ياد گيرى تأثير گَذار

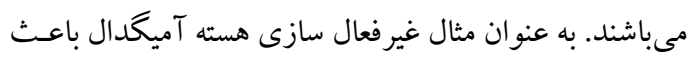

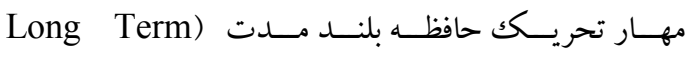
(Potentiation; LTP

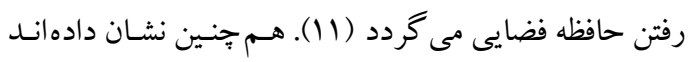
كه آميخدال به ويزه هسته BLA آن در تنظيم، تثيـت و بـهـ خاطر آوردن انـواع حافظهه نقـش دارنــ (Y I). عـلاوه بـراين اثرات استرس بر كسب و حافظه بـه ارتبـاط بـين هيبو كمـبِ وآميگدال بستكى دارد و نيز مطالعـات بـر روى انسـان نشـان داده اسـت كـه در جريـان يـاد كيرى ارتبـاط بـين هيبو كمـبِ

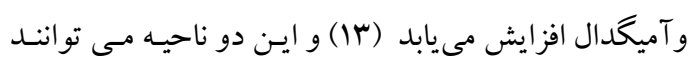
مكمل يكديخر در تشكيل حافظه باشند (If). همجينين نشـان داده شده است كه BLA در تعديل بِلاستيسيتى و القـ LTP در هييو كمـبِ نقـش دارد و سـبب افـرايش خروجـىهـــى هييو كمبِ به ساير مناطق مغز مى شود. بـراى مثـال آسـيب بـه آميخدالا اثرات تحريكى ايسىنفرين رادر افزايش حافظه.

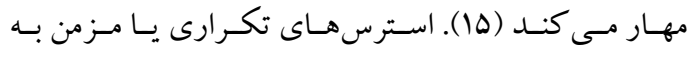

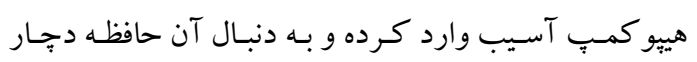
آسيب مى شود. استرس مزمن منجر به كاهش دنـدريتهـا و نـوروزنز در هييو كمـب مسى شـود. مطالعـات زيـادى بيشـنهاد
اسـترس واكسنش جسـمانى، روانى و عـاطفى در برابـر يـك مهـ

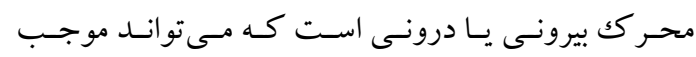

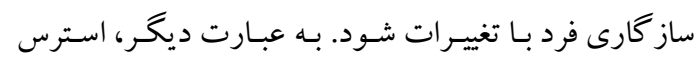
مجموعه واكنش هايى است كه در باسـخ بـه هـر عـاملى كـه

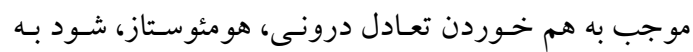

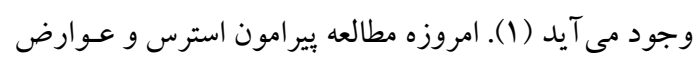

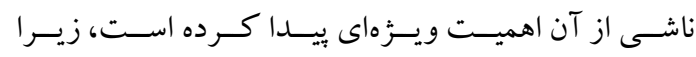

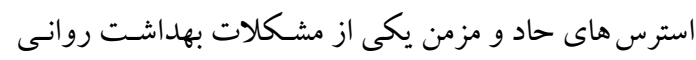
جو امـع بشـرى اسـت (Y). اسـترس خصيصـه بـارز، طبيعى و غيرقابل اجتنـاب زنـدگى اسـت و باعـث هيجـان مسى گردد. ياسخ بدن به عو امل استرسز زاى مطلق، ساز گارى بـا طبيعـت اسـت و هورمــونهـاى اسـترس (كلو كو كورتيكوئيـدها و آدرنالين) مى توانند به سـاد گى از ســ خـونى - مغزى عبـور

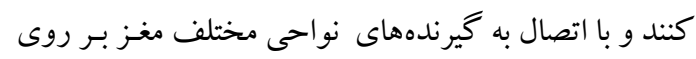

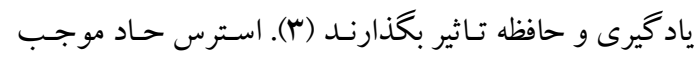
بهبـود حافظهه و اسـترس مـزمن تخريسب حافظـه مسى شـود. اسـترس تحـت مـزمن بـا توجـه بــه زمـان و نسوع آن رفتـار متفاوتى دارد (F). در دستخاه ارتباطى اعمال استرس شـو كك لـ الكتريكى كف يا، استرس فيزيكى شوكى و استرس روانى ناشى از اعمال شوكك به مـوش هـاى ديخـر بـر روى حيـوان اعمال مى شود ( ه). يُاسخ هاى استرسى شـامل تغييراتى در

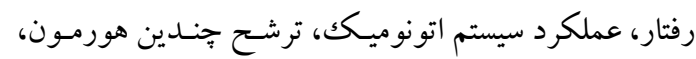

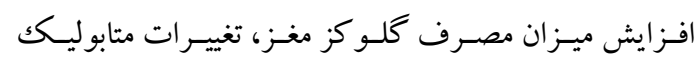
و تغييرات بافتى در مغز و آدرنال و حتى تغيير در سـطح بيـان يروتئين ها در شرايط استرس مزمن مى باشـد. اسـترس سـبب اختلال در عملكرد سيستمهاى انتقال دهنده عصبى و اختلال HPA; ) در نظمم محسور هييوتـالاموس -هيْـوفير -آدرنسال (Hypothalamic-pituitary-adrenal نواحى مختلفى از مغز در ياسخ بـه اسـترس نقـش دارنـد كـه

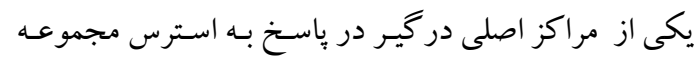

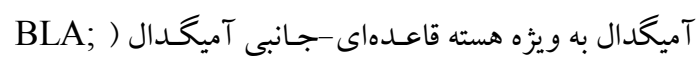
Basolateral Nucleus of the Amygdala 
ه4 اثرات تعديلى سالبوتاهول... D4

در اين مطالعه تجربى جهل سـر مـوش صحرايى (رت) نر

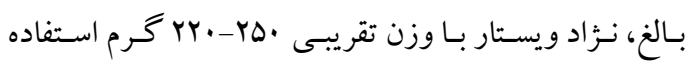

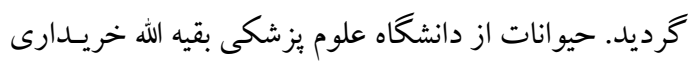

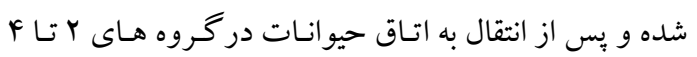
تايى در قفس هاى بِلاستيكى شفاف مخصوص

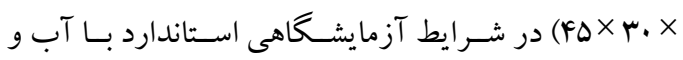

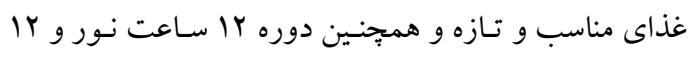

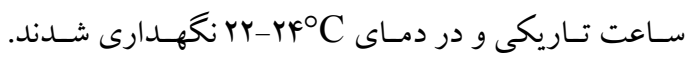

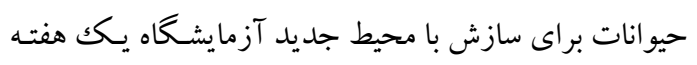

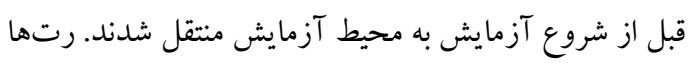

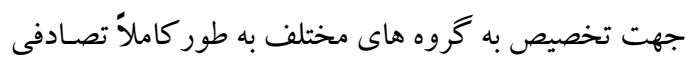

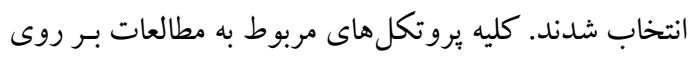

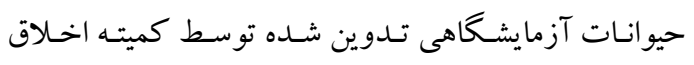

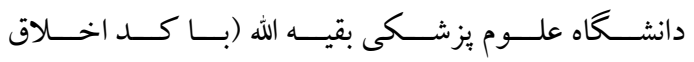
a a. (IR.BMSU.REC.1396.814 در اين مطالعه مورد توجه

$$
\text { قروره هار خرفته و رعايت شدند. }
$$

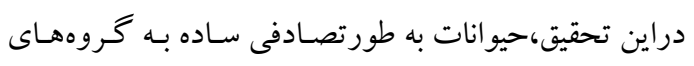

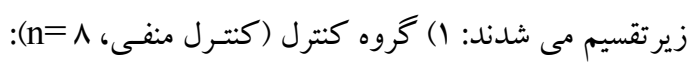

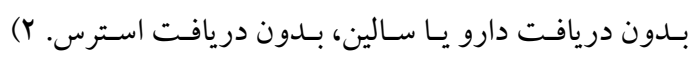

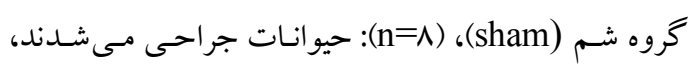

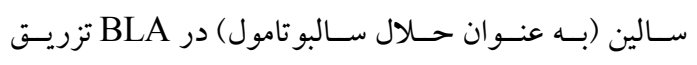

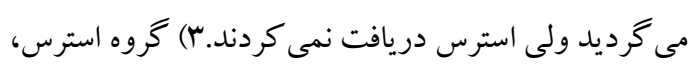
F (n=人)

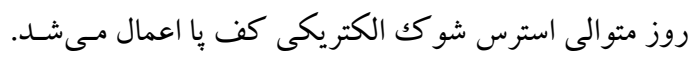

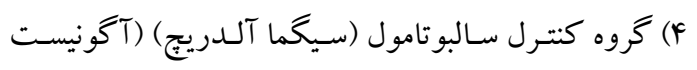

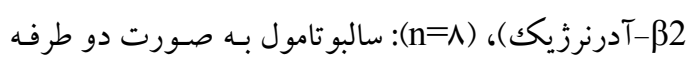

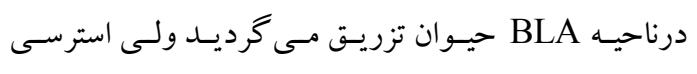

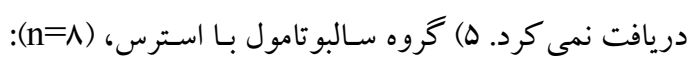

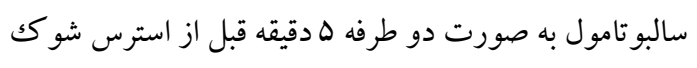
الكتريكى كف پا درناحيه BLA حيوان تزريق مى گرديد.

$$
\text { روش جراحى و تعبيه كانول راهنما : }
$$

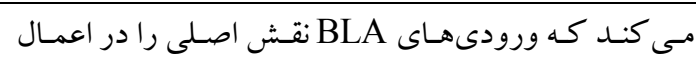

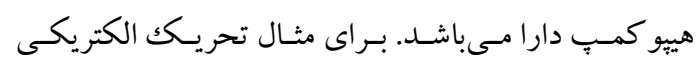

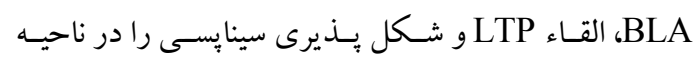

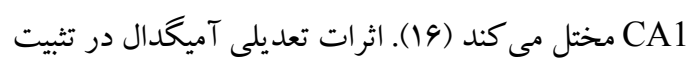

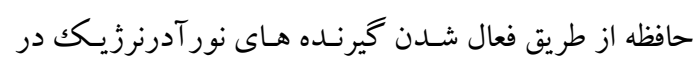

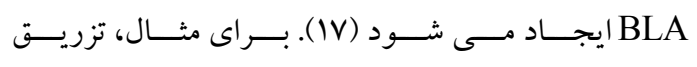
آنتا گونيستهاى بتا-آدرنرزيك در آميگدال سبب فراموشى شده در صورتى كه تزريق آكونيستهــاى بتـا-آدرنرزيكك

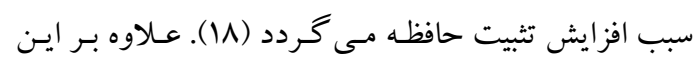

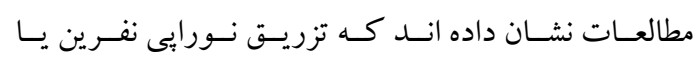

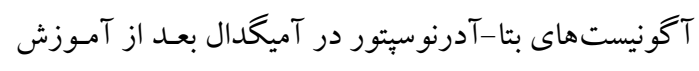
سبب افزايش ذخيره حافظه مى شود، در صـورتى كـه تزريق

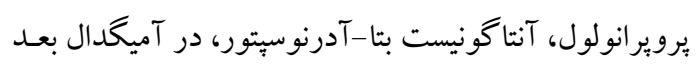
از آموزش سبب آسيب به حافظه مىشود (19).

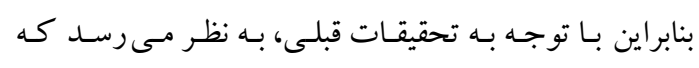

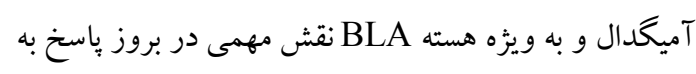

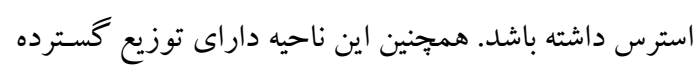

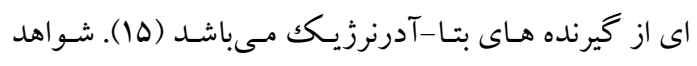

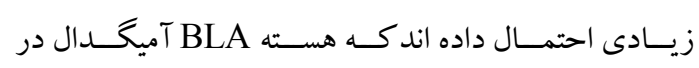

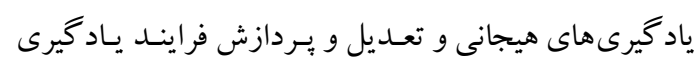

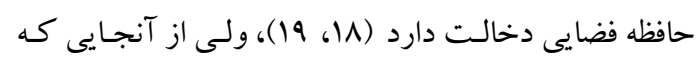

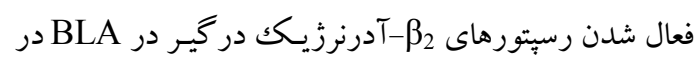
هاسخ به استرس به خوبى مشخص نيست لـذا در ايـن تحقيق

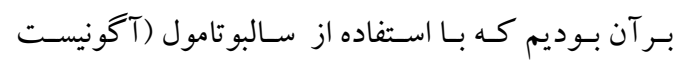

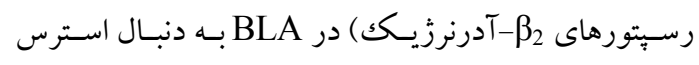
ميزان دخالت گيرندههاى موجود در اين ناحيه را بر تغييرات

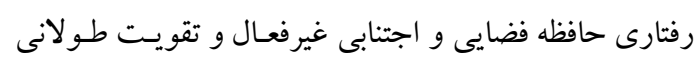

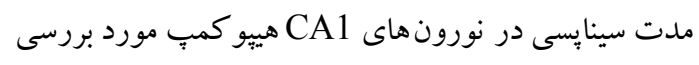

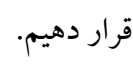

مواد و روش ها حيوانات: 
كانول راهنما تعبيـه شـده قـرارداده و دارو بـه آهستخگى و بـه

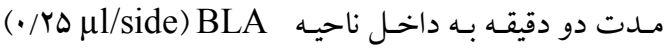
تزريق شد. سبس سرسوزن تزريق به آرامى از داخـل كـانول راهنما خارج و در سـمت مقابـل نيز بـه همسين شـيوه تزريـق انجام شد. ه دقيقه يس از تزريـق سـالين و يـا سـالبوتامول بـهـ ناحيه BLA حيو انات جهت القاء اسـترس بـه دستخاه جعبـه ارتباطى (Communication Box) انتقال داده شدند. روش القاء استرس شوكى الكتريكى كف بِ توسط دســاه

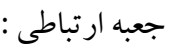
ايسن دسـتخاه (شـركت بـرج صـنعت آزمـا، تهـران، ايسران) ازجنس يلكسى گلاس بوده كه كاملاً شفاف است و داراى

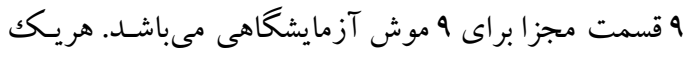

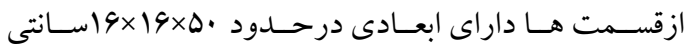

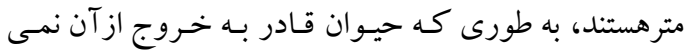
باشد. كف دستگاه حاوى سيمهاى استيل ضد زنگك بـه قطر

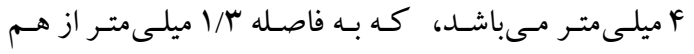
قرار گرفته و به دستگاه الكتروشوكى كه توسط رايانه كنترل مىشود، ارتباط مى يابد. در تحقيق حاضر، شوك الكتريكى

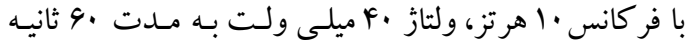

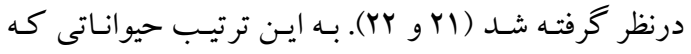

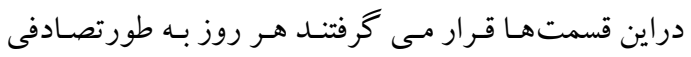
شـوك الكتريكـى تنظـيم شــدهاى را (كـهـ نـوعى اسـترس فيزيكى محسـوب مسى شـود) دريافت مسى كردنــ. از طرفى غيرقابل گريز بودن محفظه دستخاه را به عنوان جـزء روانى مئى استرس مىبايست درنظر كرفت. آن دسته ازموشهـايى كـه تحت استرس قرار مى گرفتند، هد دقيقـه قبـل از آن سـالين يـا دارو (سالبو تامول) دريافت مسى كردنـــ. يـس از بِايـان يـافتن استرس يكك ساعت فرصت داده مى شد تا موش ها آرام شده و از شوكك ناشـى از اسـترس خـارج شـوند. ايـن روش القـاء استرس در \& روز متوالى انجام شد. اما در هر روز زمان القـاء استرس تغيير كرده و به صورت تصادفى در سـاعات مختلـف

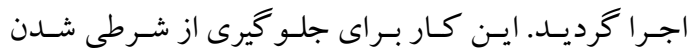

$$
\text { حيوانات نسبت به زمان القاء استرس بود. }
$$

ابتدا رتها از حيو انخانه به محل آزمايش انتقال داده شـده و جهت بيهوشى حيوانات كلرال هيـدرات (سـيخما آلـدريج) (rه. mg/kg) از بيهوشى كامل حيـوان آن را درون دستخاه اسـترئوتاكس فــــاكس نمــوديم. (Stoelting, Wood Dale, IL) مختصـات استرئو تاكسى ناحيـه BLA بـا توجـه بـه اطلـس

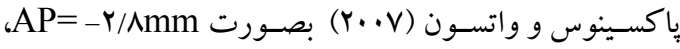

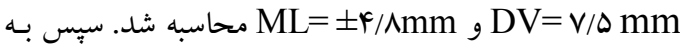
و سيله مته دندانيز شكى سـوراخى در محـل علامـت خـذارى شده بر روى جمجمه ايجاد شــ كـه ايسن سوراخ بـه قطر 1 ميلى متر بوده و تا يـرده منتـز ادامـه داشـت. قبـل از كذاشـتن كانول راهنما (Alibaba; INTR) ييجج هاى ريز عينكك در حد فاصل r ميليمترى محل قرار گيرى كانول بر روى سـح جمجمه جهت محكم نخه داشـتن كـانول راهنمـا تعبيـه شـد. بعد از سوراخ كردن جمجمه كانول راهنما به كمك دستگاه اسـتريوتاكس بـه آرامسى وارد مغـز شــده سـبس بـه سـرعت

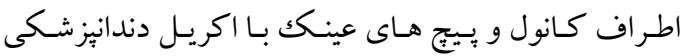
مخلوط شـده بـا منـومر بوشيده شـده و بعـد از سـفت شــدن سيمان دندانيزشكى به آرامى سوزن دستخاه استريو تاكس را از درون كانول خارج كرده و سيمى از فولاد زنگك نزن كه. به اندازه ارتفاع كانول ساخته شده بود را درون آن قرار داده

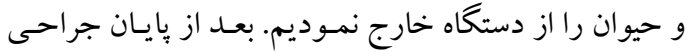
حيوان در قفس انفر ادى قرار داده شـــ و بــراى سـيرى شــن دوره بهبودى V روز به حيـوان اسـتراحت داده و بعـد از ايـن

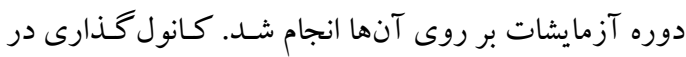
ناحيه BLA به صورت دوطرفه انجام شد. روش تزريق دارو در BLA: تزريق سالين يا سالبو تامول (F BLA رابط بلى اتيلنى به سرنگك هاميلتون وصل شده بود، صسورت كرفت. طول سرسوزن تزريق يـك ميليمتـر بلنـدتر از كانول راهنما انتخاب شد. درابتدا لوله يلى اتيلنى و سرسوزن تزريق با سالين و يا سالبو تامول يُر شــ. ســـس سرسـوزن تزريـق در 
اثرات تعديلى سالبوتاهول...

فوق شسته ميشد. يار امترهـاى مـورد بررسى جهـت سـنجش

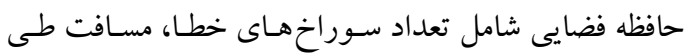
شده توسط حيوان و زمان رسيدن به سوراخ هدف بود. تست ياد گيرى احتـرازى غيرفعـال ( Passive-avoidance :(test Shuttle ( براى انجام اين تسـت از دستخاه شـاتل بـاكس (شركت برج صنعت آزما، تهران، ايران) تشكيل شـده (box

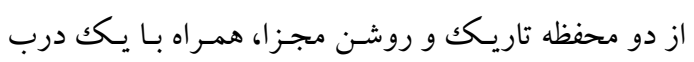
كيوتينى قابل كنترل بين دو محفظه استفاده شد.

مرحله سازش يذيرى (Adaptation trial)

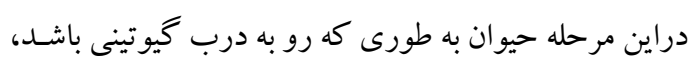

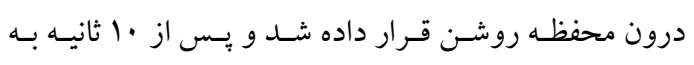

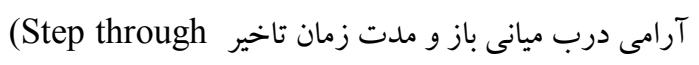
- براى ورود حيوان به بخش تاريكك ثبـت latency; STL) شد. در صورتى كه اين زمان بيش از · .ب ثانيه بـود بـه دليـل عدم تمايل حيوان به بخش تاريـك حيـوان ازمطالعـه خـارج مى شد. مرحله آموزش (Training trial): دو سـاعت يسس از مرحلـه سـازش بــذيرى، حيـوان همجِون مرحله قبل درون محفظه روشن قرارگرفـت، بـا ايسن تفـاوت كه به محض ورود حيو ان به محفظه تاريكك درب بسته شـده فيه و به كف دست و ياى حيوان شو كك الكتريكى با شدت ها ه • ميلى آمير و فر كانس •ه هرتز به مدت ب ثانيـه اعمـال شـد و بس از • ب ثانيه حيوان را از دستكاه خارج كرديم و ب دقيقـه

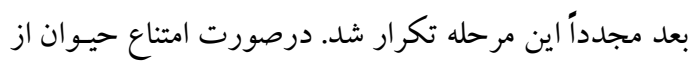
ورود به بخش تاريـك در دفعـات دوم و سـوم آمـوزش، بـهـ آرامى حيوان را با دست به محفظه تاريـك هـدايت شـده و شوكى اعمال كرديد. مرحله آمـوزش حسداكثر جهار مرتبـه تكــرار شـــ (YN). ايسن مرحلـه در روز اول اسـترس انجــام كرديد.

مرحله يادآورى (Retention trial)

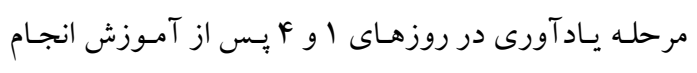

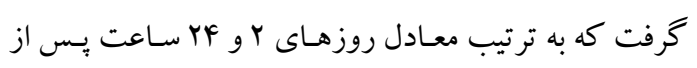

روش ارزيابى حافظه فضايى به وسيله ماز بارنز :

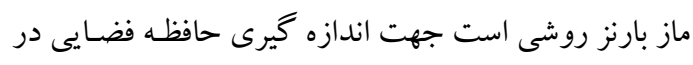
موشهاى كوجّك آزمايشگاهى و موش صحر ايى. ايسن مـاز

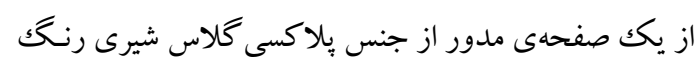

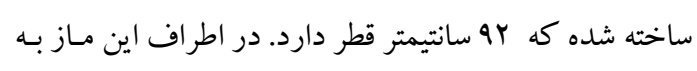
فاصلهى ץ سانتيمتر از لبهى ماز rا سوراخ به قطر ^ سـانتيمتر

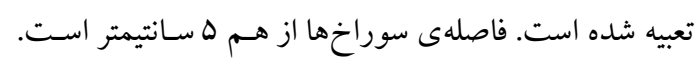
در زير يكى از اين سوراخها (سوراخ هدف) يكك اتاقكك از

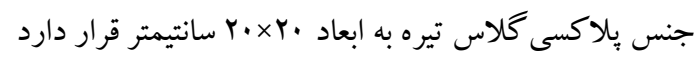
كه مى تواند از يكك سوراخ به سـوراخ ديخـر جابـهــا شـود. اين ماز بر روى يكك يايه به ارتفاع · ·. سانتيمتر قـرار دارد و

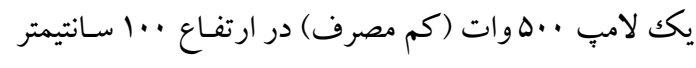
بالاى آن تعبيه شده است. براى آموزش حيوانات، هر حيوان

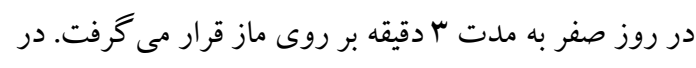

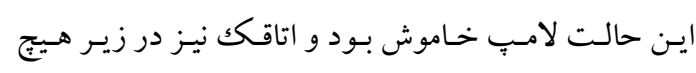

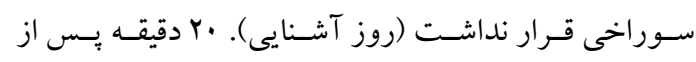
آشنايى، ابتدا اتاقك در محل خود قرار مسى گرفت، حيـوان

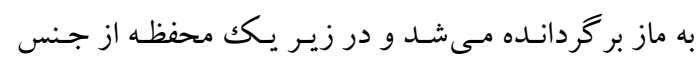

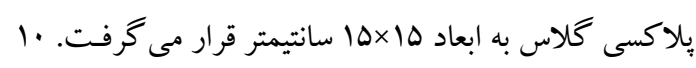

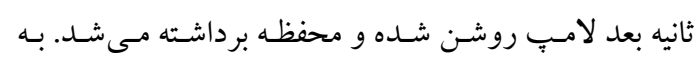
حيوان ·ه ثانيه وقت داده ميشد تا سوراخ هدف را بيدا كنـد.

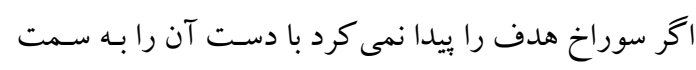
سـوراخ هـدف هـدايت مسى كـرديم. بـس از يـافتن سـوراخ

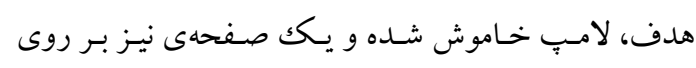
4. ثانيه حيو ان در همان حالت باقى مى ماند. اين روش ع ب بـار در

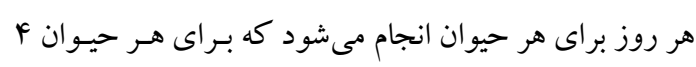

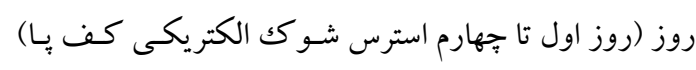

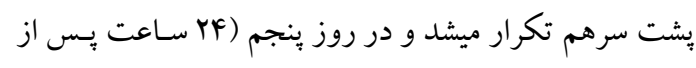

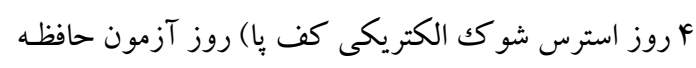

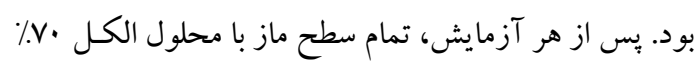

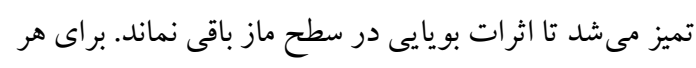
حيوان هم اتاقك مقصد بيش از شـروع آزمايش بـا محلـول 


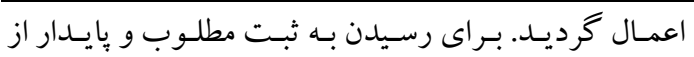
ناحيه CA1 گاهى ضرورت داشت جاى الكترود تحريكك و

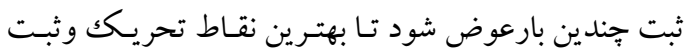

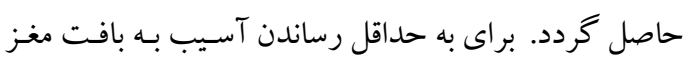

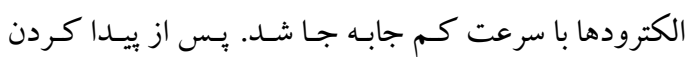
جاى مناسب وتعيين دقيق محل ثبت و تحريكك، تحريكـات

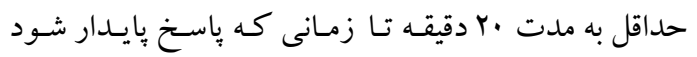

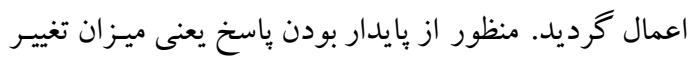

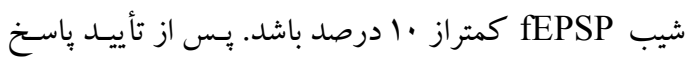

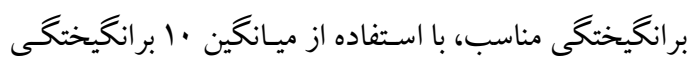

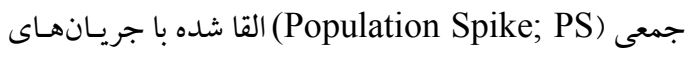

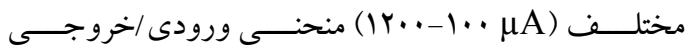
(Input/Output curve; I/Q)

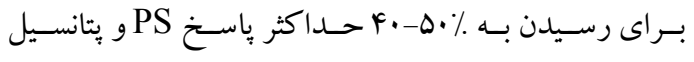
تحريكى بس سينايسى ميـدانى ( field Excitatory Post I/O بوسـيله منحنـى Synaptic Potential; fEPSP

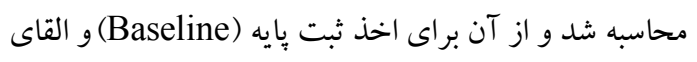
يتانسيل طولانى مدت (LTP) استفاده شد. ثبـت بِايـه باسـخ

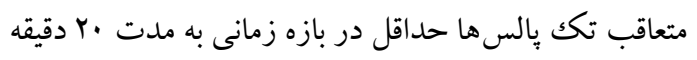

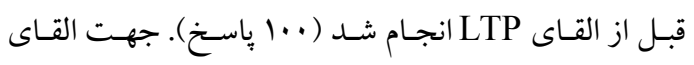

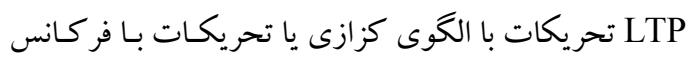
بالا (HFS; High Frequency Stimulation) (• الدوره

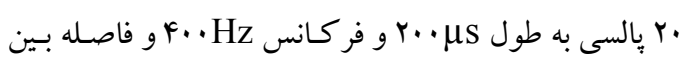

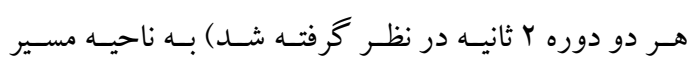

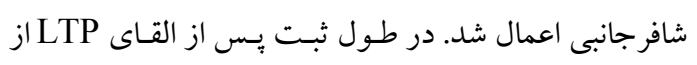

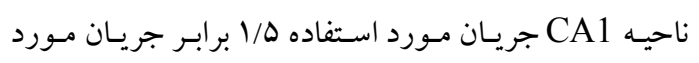

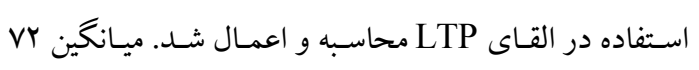

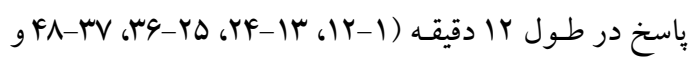

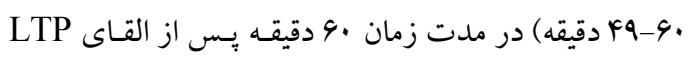

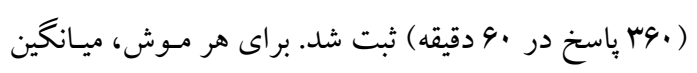

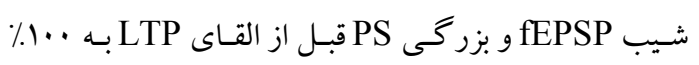

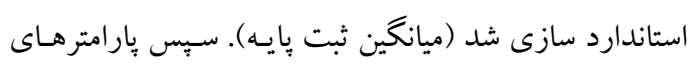

روز F استرس شو كك الكتريكى كف يا بودند. بدين صورت كه همجون مر احل قبل حيوان در محفظه روشـن قرار داده

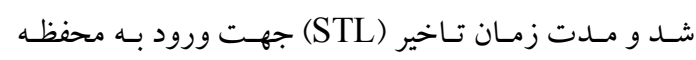

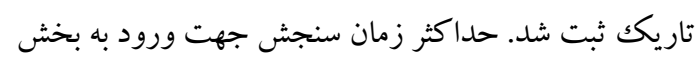

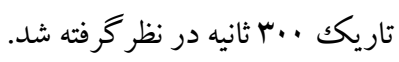

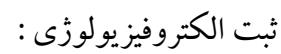

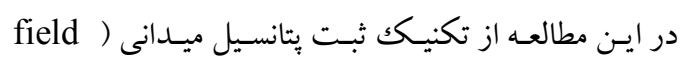
(شر كت برتو دانش، تهران، ايران) (potential recording استفاده شـد. مسير شافر جـانبى(schaffer collateral)

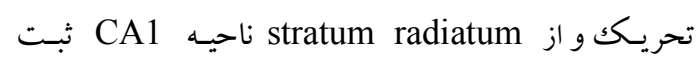
صورت گرفت. در اجراى اين تكنيك از الكتـرود از جـنس ناحس

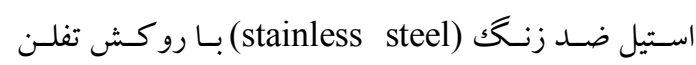
(PFA-Coated Stainless Steel, Diameter: 0.005 inch; A-M system, USA)

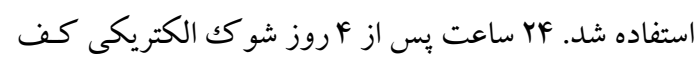

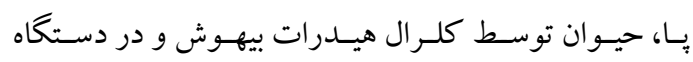

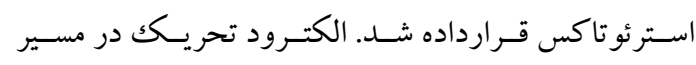

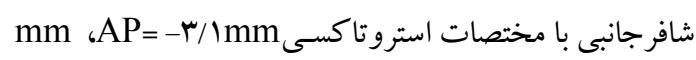

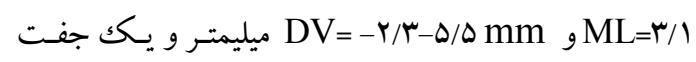
الكترود بعنوان الكترود ثبـت در ناحيـ CA1 هييو كمـبِ بـا و مختصات استرو تاكسى AP

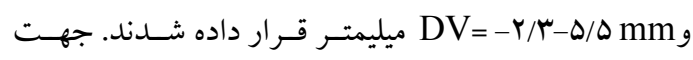

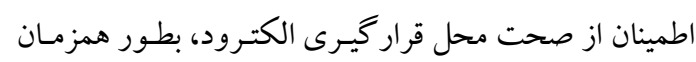

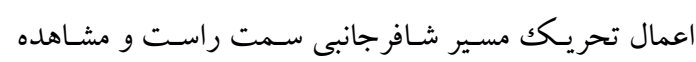

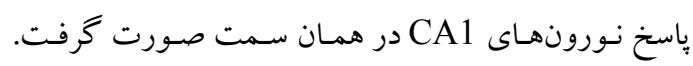
الكترود رفرانس را نيز به يكك بييج عينكك متصل كرده و بييج

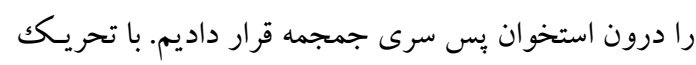

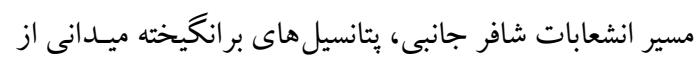
ناحيه استراتوم رادياتوم CA1 ثبت گرديد. دستور تحريكك

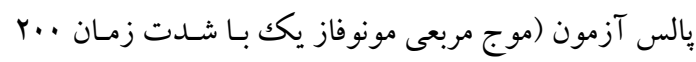

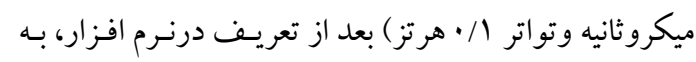
قسـمت Data Acquisition ارسـال و بعـد از كذشـتن از ايزولاتور، توسط الكترود دو قطبى بـه مسير شـافر كولترال 
40

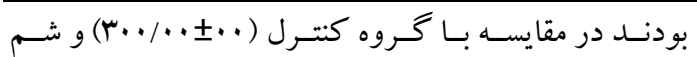

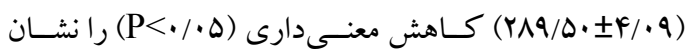
دادند (شكل ا-ب). علاوه بر اين، هفـت روز يـس از اولين استرس (روز هفتم بعد از اولين روز استرس) زمان تـاخير بـه بـ بـ بـ صـورت معنى دارى (ه •/P> (P) در رت هـاى اسـترس ديـده (190/0 • ( IN/VFV)

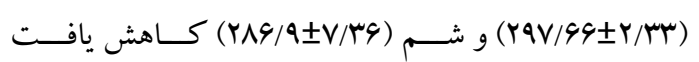

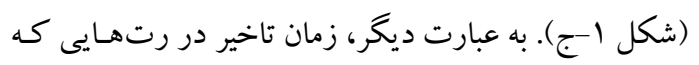

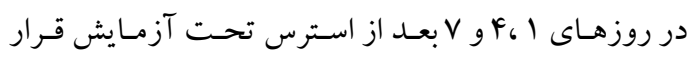

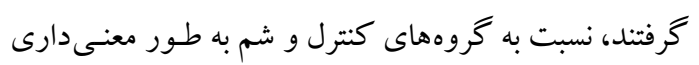

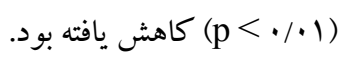
نتايج حافظه احترازى غيرفعال در شاتل باكس نشـان داد كـه لـ در حيوانات گروه كنترل سالبوتامول به صورت معنسى دارى

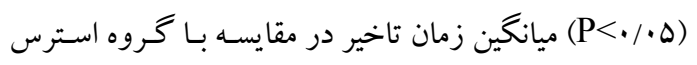

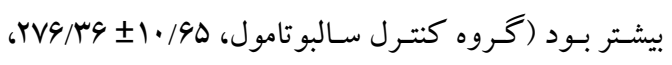
سM/F

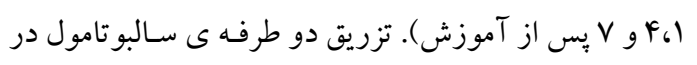
ناحيه BLA ه دقيقه قبل از استرس (n=^) در رتها (كروه سالبو تامول و اسـترس) افز ايش معنسى دارى (1 • • > p) در ميانكين زمان تاخير نسبت به گروه استرس در روز اول نشـان داد. از طرفى نتايج نشـان داد كـه ثل روز يـس از استرس و ل روز يس از اولين روز اسـترس تزريـق سـالبوتامول در BLA

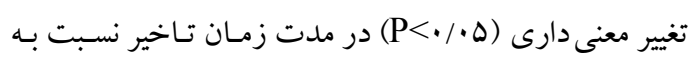

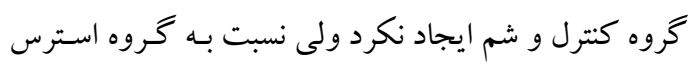

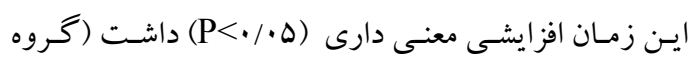
سـالبوتامول و اسـترس: وع/11/

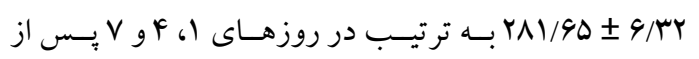

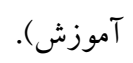

محاسبه در هر بازه زمانى يسس از القـاى LTP، بوسيله ثبـت يايه استاندارد سازى شدند. روش تجزيه و تحليل داده ها: در اين تحقيق، براى بررسى وجـود تفـاوت معنىدار بـين

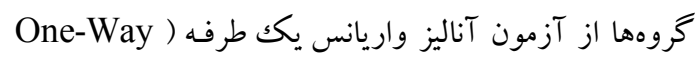
Post-hoc , Analysis of Variance: ANOVA متناسـب داده هـا (Tukey)، بـا استفاده از دو نـرم افزار Prism Pad Graph و SPSS اسـتفاده شـــ. بـراى تسـت بارنز از آزمون آنـاليز واريـانس دوطرفه ( Two-Way repeated (Analysis of Variance: ANOVA measure انحراف معيار ميانگين براى هر گروه در نظر گرفتـه شـد و در تمامى مراحل P>0.05 به عنوان سطح معنىدار بـودن در نظر كرفته شد. يافته ها اثرات تزريق داروهاى احترازى غير فعال: - مترال تزريق سالبو تامول به صسورت دوطرفه در BLA يـنج دقيقـه قبل از استرس و هـم جنــين در شــرايط بـــون اسـترس انجـام شد. نتايج نشان داد استرس شوكى الكتريكى كف يـا باعـث

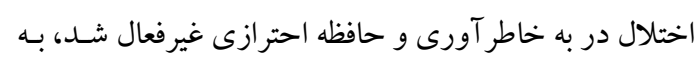

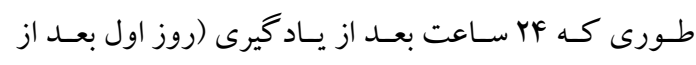

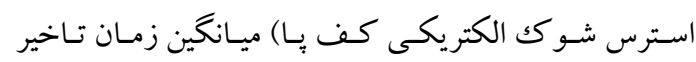

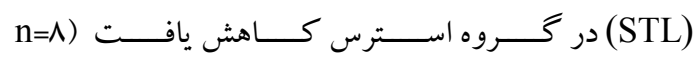

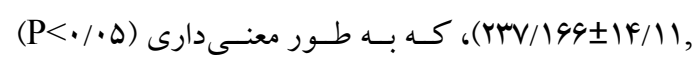
نسبت به گروه كنترل (1)

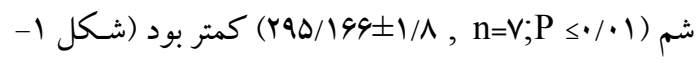
الف). در روز جهارم آموزش (روز جهارم اسـترس)، زمـان تـاخير

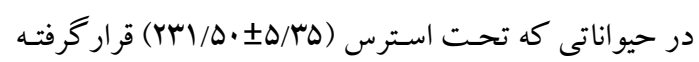




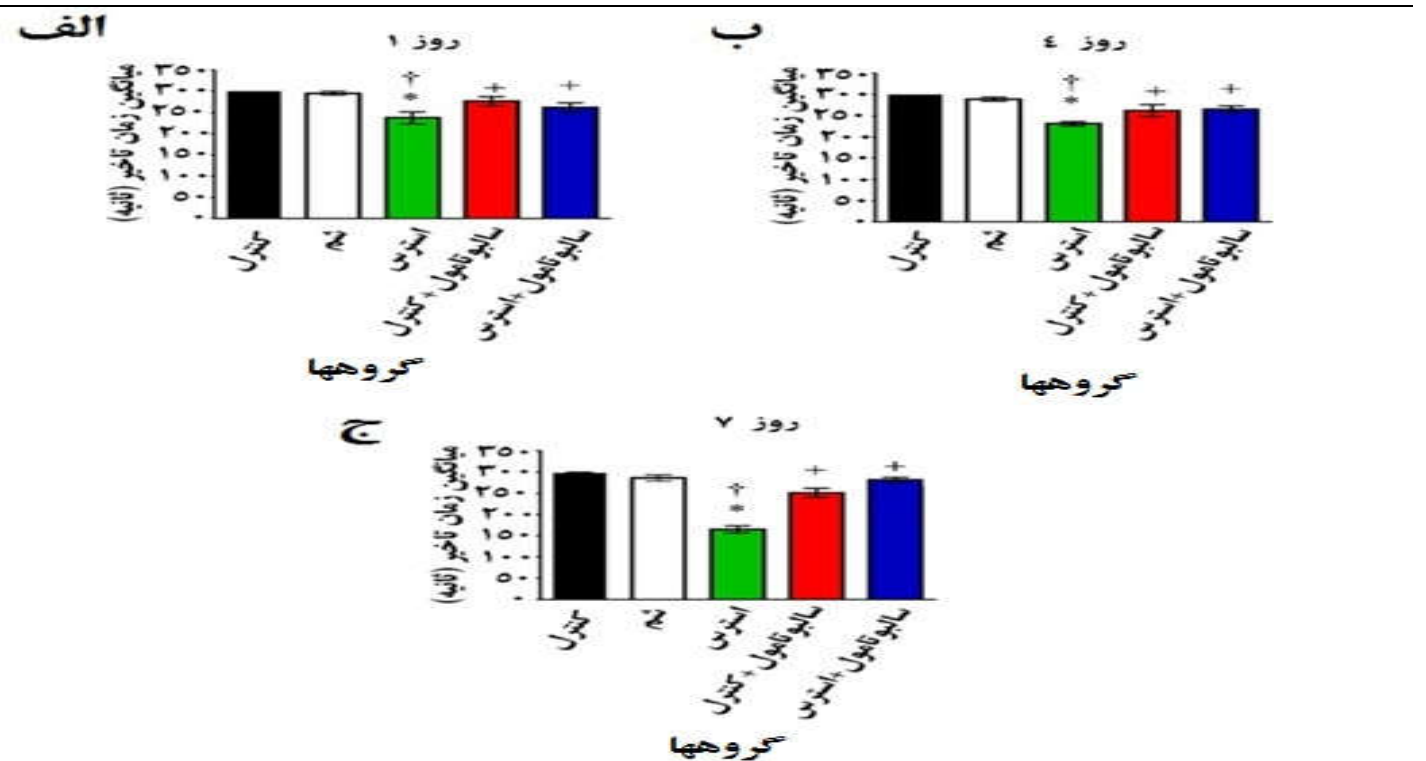

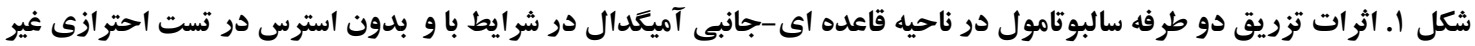

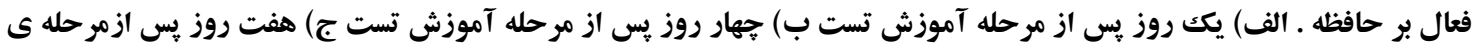

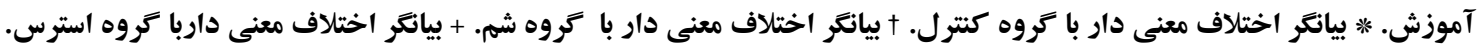

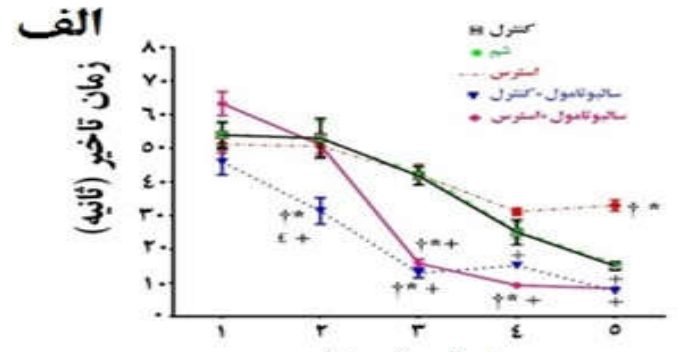

زمان (روز)
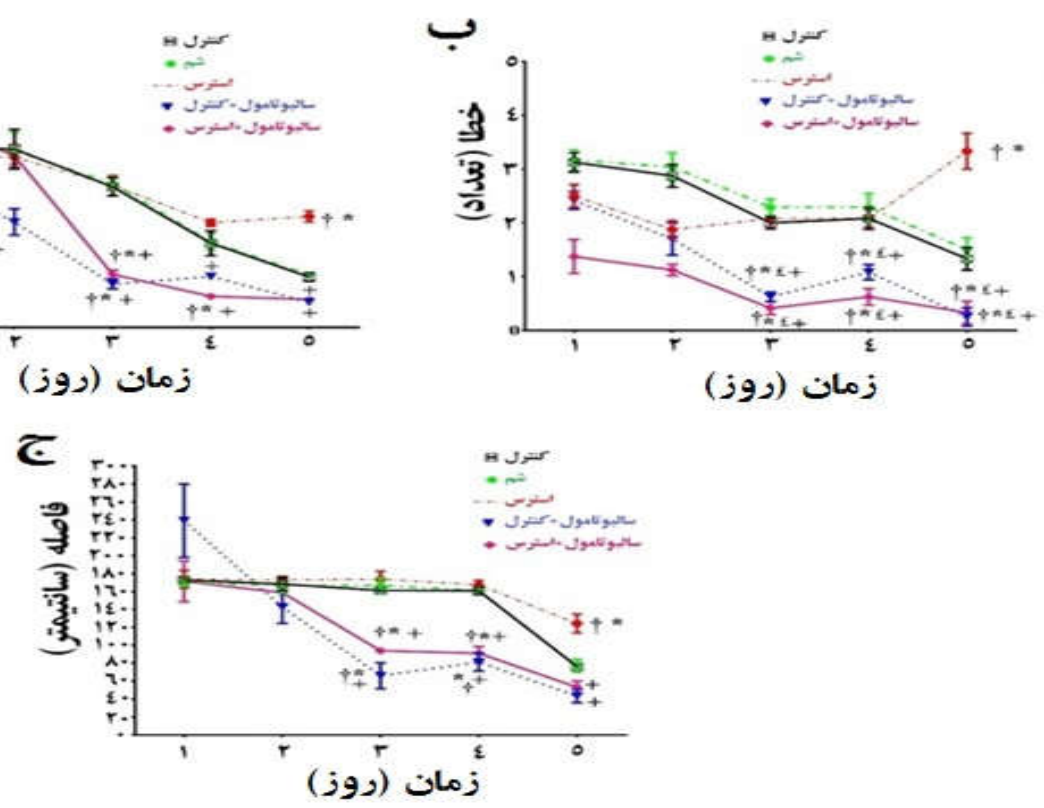

شكل ז. اثرات تزريق دو طرفه سالبوتامول در ناحيه قاعدهاى-جانبى آميعدال در شرايط استرس و بدون استرس در تست بارنز.

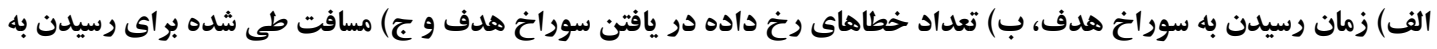

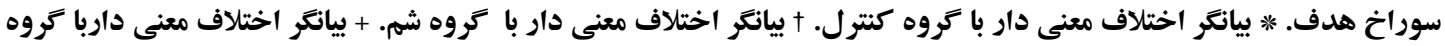
استرس. £ بيانكر اختلاف معنى دار با كروه سالبو تامول+استرس. 
4 اثرات تعديلى سالبوتاهول...

تغييرى معنادارى مشاهده نشد. هم جنان كـه در شـكل ب-ب نشان داده شده است، رت هايى كه به صورت دو طرفه در سالبو تامول را ينج دقيقه قبل از اسـترس دريافت كرده

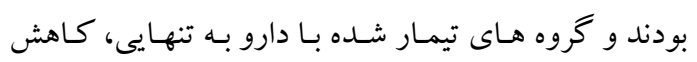

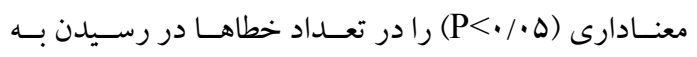
سوراخ هدف نسبت به گروه استرس نشان دادنـد، ولى بـين

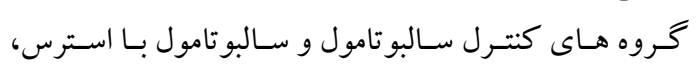

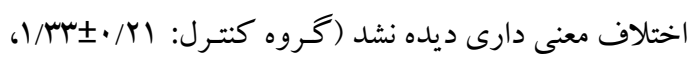

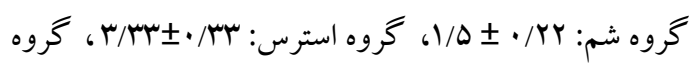

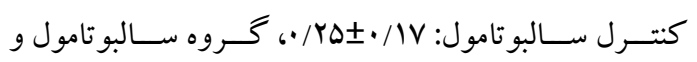

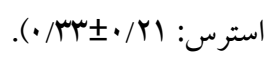
نتايج مسافت طى شده براى رسيدن به سوراخ هـدف در اثر تزريـق دوطرفـه سـالبو تامول در ناحيـه BLA در تسـت مـاز

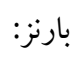
نتايج نشان داد كه مسافت سيرى شده به تدريج در طى يـنج روز كاهش يافت. ولى هـم جنـان كـه در شكل بـان نشـان داده شده است رت ها با تيمار به وسيله سالبو تامول از طريـق تزريق دوسويه در BLA ينج دقيقه قبل از استرس به صورت

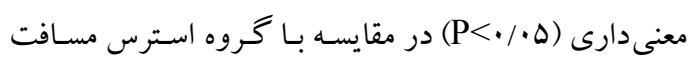
كمترى را طسى كردنـد (كروه كنترل معنى گ گروه شـم

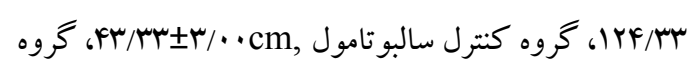
سـالبو تامول و اسـترس: يتانسيل ميدانى در ناحيه CA1 هييو كمب در اثر تزريتق دو طرفه سالبوتامول در ناحيه BLA:

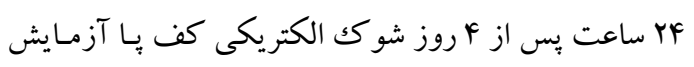

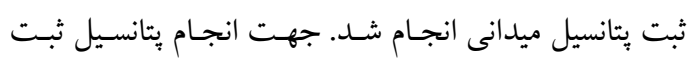
ميدانى از طريق الكترودهاى قرار گرفتـه شـده در مسيرشـافر

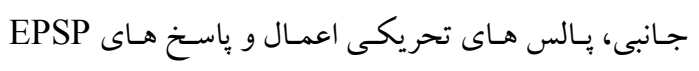

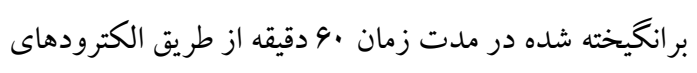
تعبيه شده در سلول هاى ناحيه CA1 در موش ها ثبت و سـه

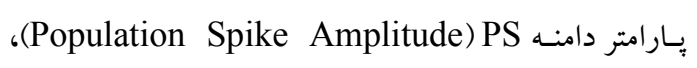

اثـرات تزريـق آكونيسـت حافظه فضايى: نتايج زمان رسيدن به سوراخ هـدف در اثر تزريـق دو طرفه آكونيسـت

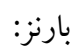
نتايج نشان دادند كـه در طـول دوره يـنج روزه تسـت بـارنز،

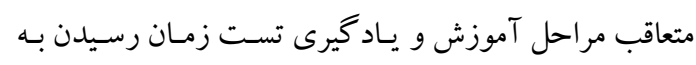
سوراخ هدف در همه گرووها روند كاهشى داشتند. از سوى مرى ديخر اين زمان در روز ينجم در همه خروه ها نسبت به زمـان

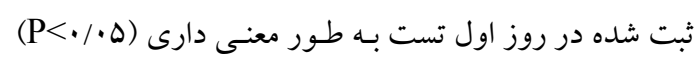
كاهش يافته بود. ولى همان كونه كه در شكل ب-الف نشـان داده شده است، در روز ينجم تست بارنز حيواناتى كه جهار

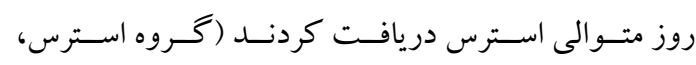
سو/1 رسM)، براى رسيدن به سوراخ هدف در مقايسه با گرووه

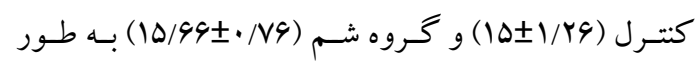
معنى دارى (1/ P> P) زمان طولانى ترى را سبرى كردند. در كروهـى از حيوانـات كـهـ تزريـق دو طرفـه سـالبو تامول در BLA

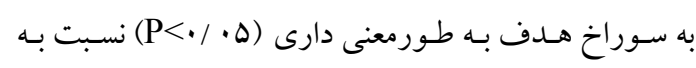
كروه استرس كو تاهتر بود. ولى همان گونه كـه در شكل بـ الف ديده مى شود زمـان رسـيدن بـه سـوراخ هـدف در بـين

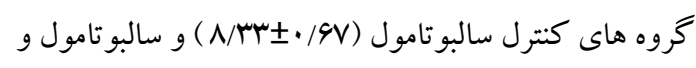

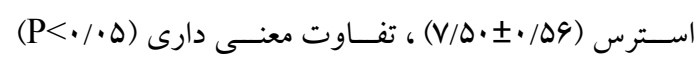
مشاهده نشد. نتايج تعداد خطاهاى رخ داده در يافتن سوراخ هدف در اثر

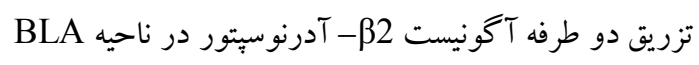
در تست ماز بارنز : مروني تعداد خطاهايى كه حيوانات در مدت يكسـان بـراى رسـيدن به سوراخ هدف در صفحه بارنز درجريان ينج روز، مرتكب شدند در تمام گروه ها مورد ارزيابى قرار گرفت. نتايج نشـان داد كه در طول ايسن دوره ى يـنج روزه بـا افز ايش جلسـات آموزش تعداد خطا ها در تمام گروه ها، به جز گروه استرس كـاهش يافـت. در حـالى كـه در گـروه هـاى شـم و كنتـرل 
بررسى قرار گرفت. ميانگين شيب محاسبه شـده بين گروه

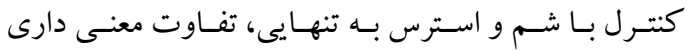

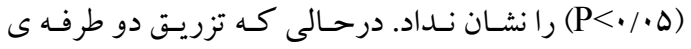

سالبو تامول در BLA، قبل از القا استرس كاهش معنى دارى

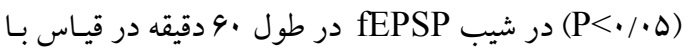

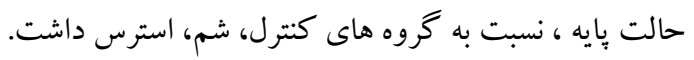

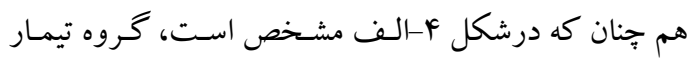

شده با سالبوتامول بدون استرس تغيير معنى دارى (ه•/P<)

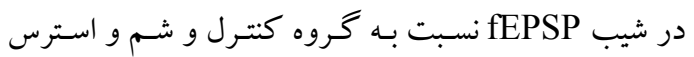

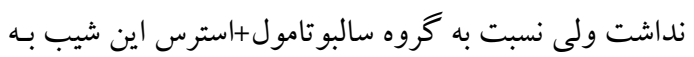

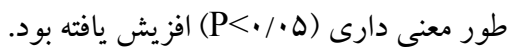

spike onset (در نهايـت، زمــان تـاخير شــروع باســخ (latency

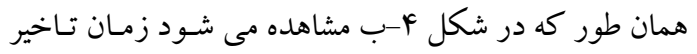

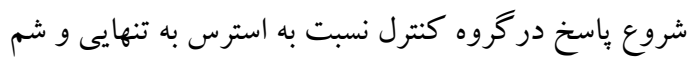

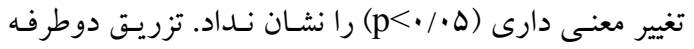
سالبو تامول در BLA در شرايط استرس (گروه سالبو تامول+

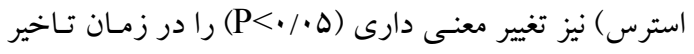

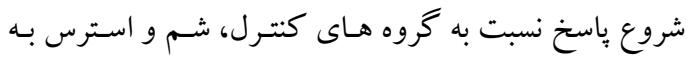

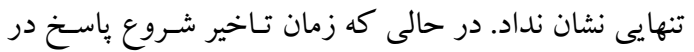

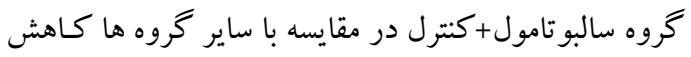
معنى دارى (ه/• (p) يافته بود.
شيب fEPSP و زمان تاخير شـروع باسـخ Spike onset) latency)

اين بارامترها براى •و دقيقه و در فو اصل زمانى: · تاه، و

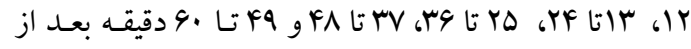

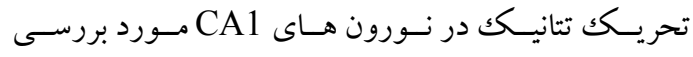

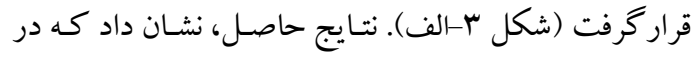

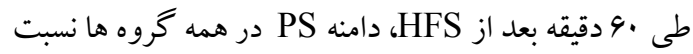

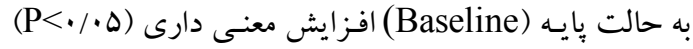
يافت (كروه كنترل: حالـت بايسه، گ گـروه شـم:

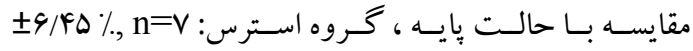

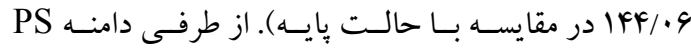

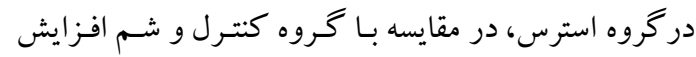

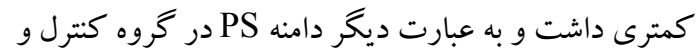
شم در مقايسه با حالت يايه در مدت .9 دقيقه بعد از HFS

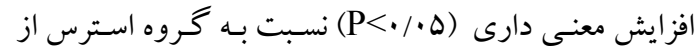

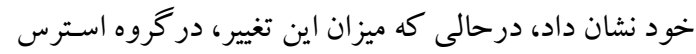

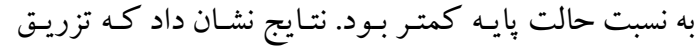
سالبوتامول ينج دقيقهـ قبـل از القـاى اسـترس، كـاهش معنـا

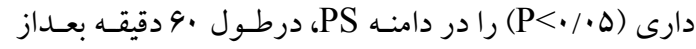

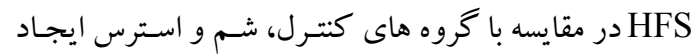

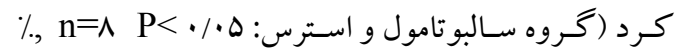

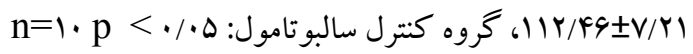

. (IFF/GY $\pm Y / D) \%$,

عـلاوه بـراين، تزريق سـالبو تامول بـه تنهايى و بـدون القـاى

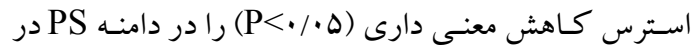
مقايسه با كروههاى كنترل و شم ايجاد كرد، ولى در مقايسـه دارئ

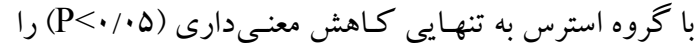

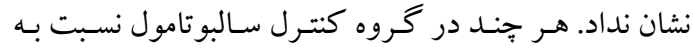
كروه سالبو تامول و اسـترس دامنـه PS افز ايش معنى دارى

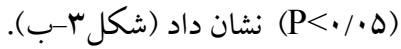

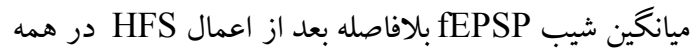

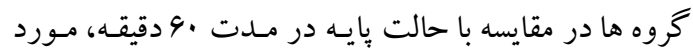




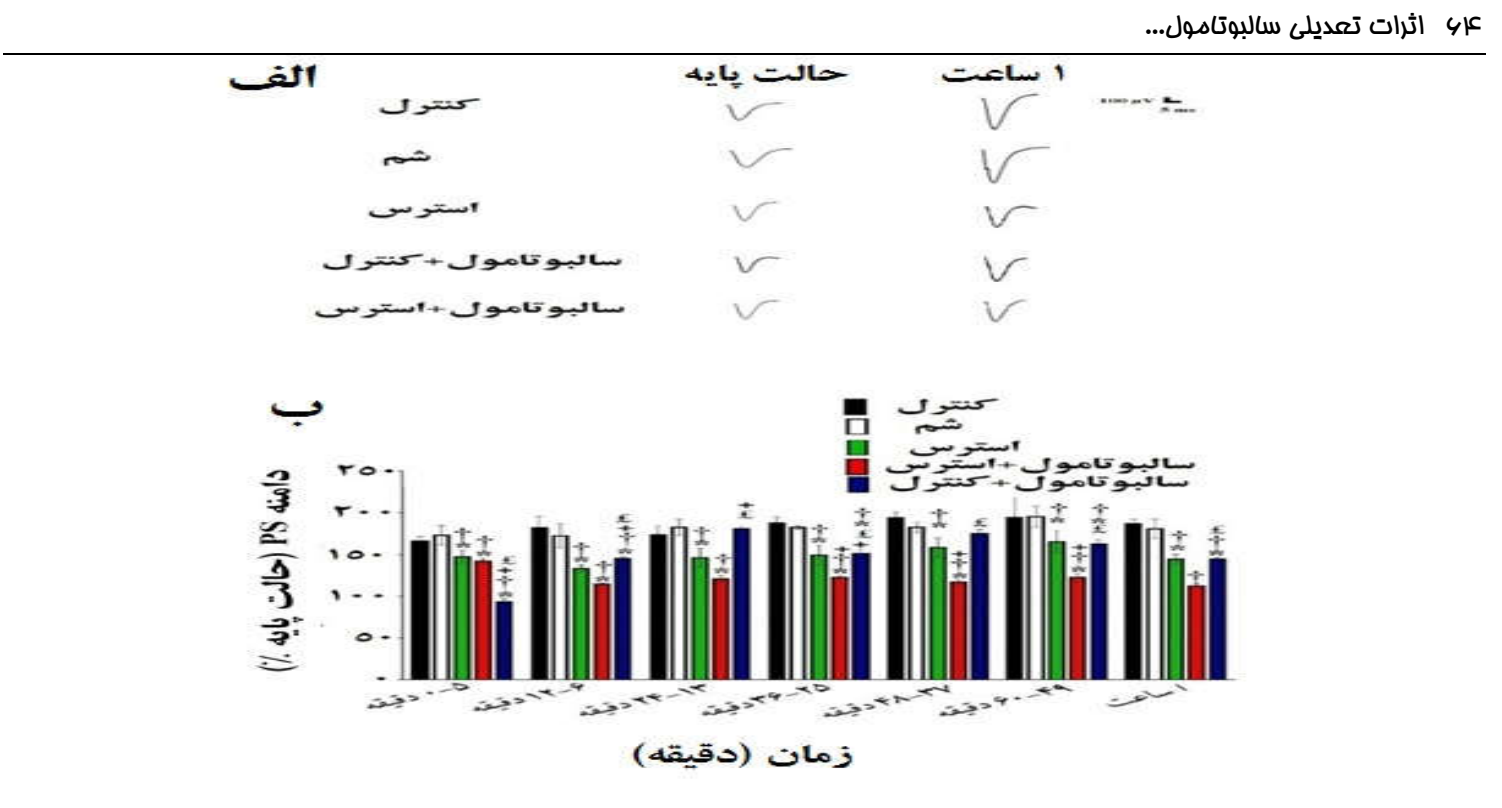

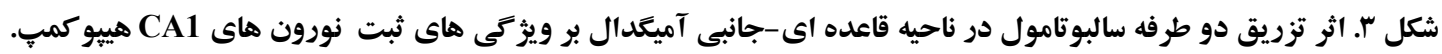

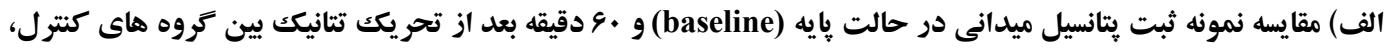

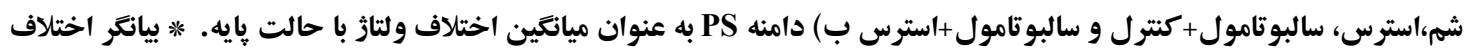

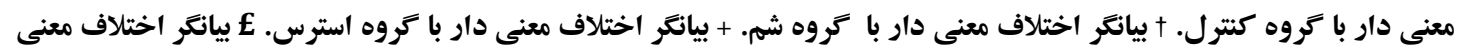
دار با تروه سالبوتامول+استرس.
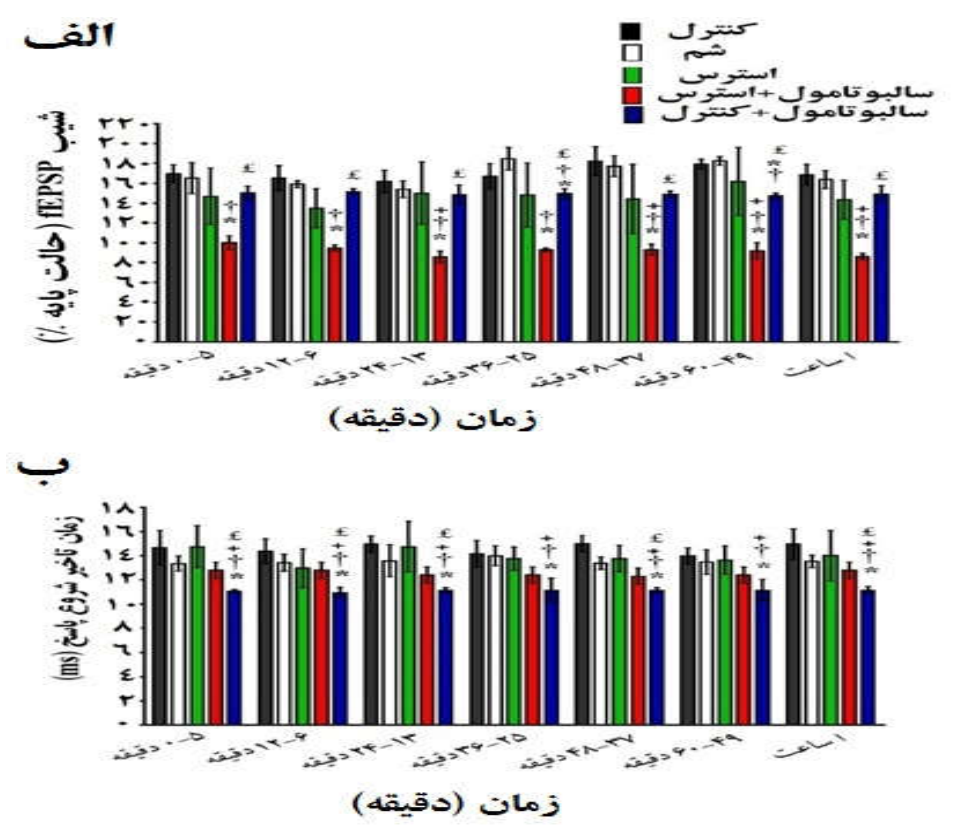

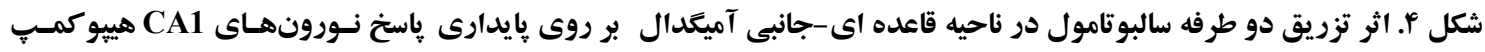

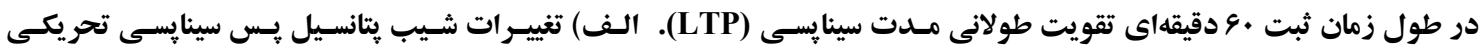

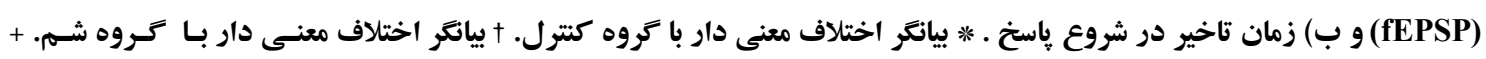

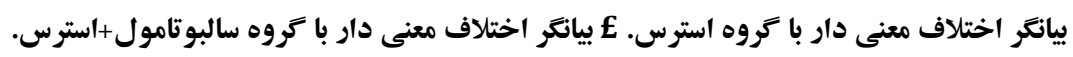


مى كند. مطالعات مختلفى اثرات استرس مـزمن را بـر اعمـال وابسته به هييو كمبٍ مورد ارزيابى قرار دادهانـــ. بـراى مثال تخريب حافظه فضايى بـر اثر استرس در مـاز آبى مـوريس

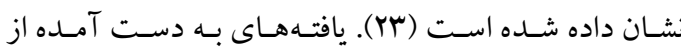
مطالعات رفتارى در انسان و حيوانات نشان داده است كه بـهـ

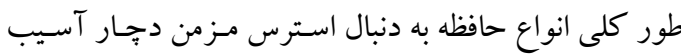

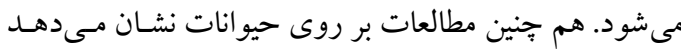

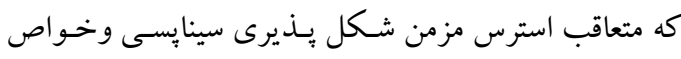
نورونى هييو كمبٍ با تغيير مواجه مسى شود. مطالعات نشـان

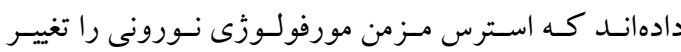

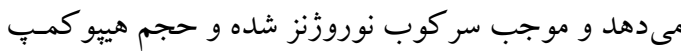

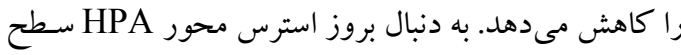

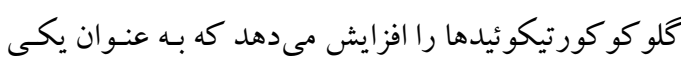
از واسطههاى اثرات استرس بر هييو كمبِ بـه شـمار مى رود

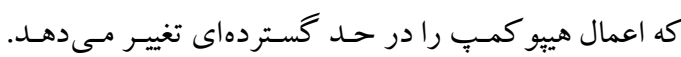

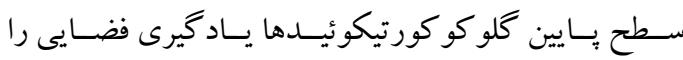

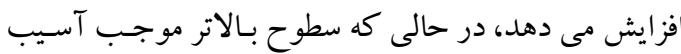

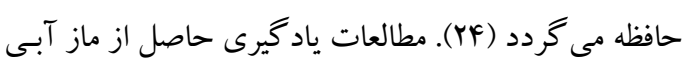

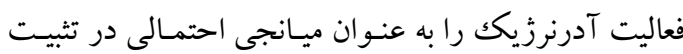

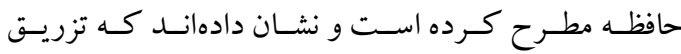

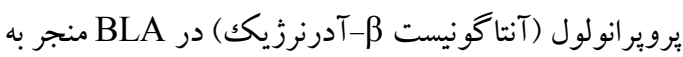

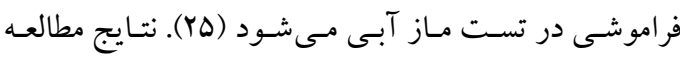
حاضـر نشـان داد كـه اسـترس مـزمن سبب كـاهش حافظهـ فضايى مىشود. هم راستا با نتايج مـا، در سـاير مطالعات در

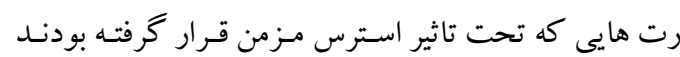

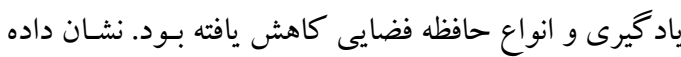

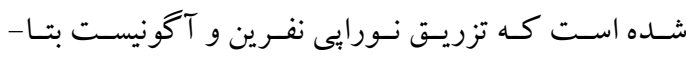
آدرنرزيكك در درون هسته هاى قاعده اى-جـانبى آميخدال

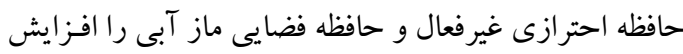

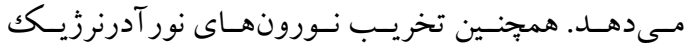

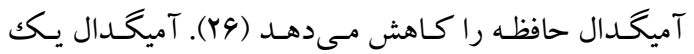

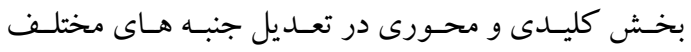

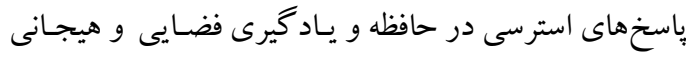

بحث درتحقيق حاضر نقش گيرنده هاى

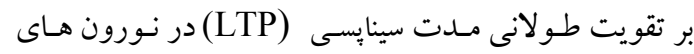
هيبيو كمب، حافظه هيجانى و حافظه فضـايى بـه دنبـال

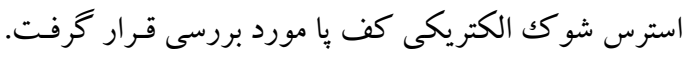
به عبـارت ديخـر هـدف از مطالعه حاضـر ايـن بـود كه آيـا فعاليـت گيرنـدهــاى حافظه هيجانى و فضايى و نيز تقويت طولانى مدت سينائس

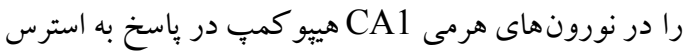
غيرقابل اجتناب تغيير دهد؟ همان گونه كه در بالا ذكر شـده،

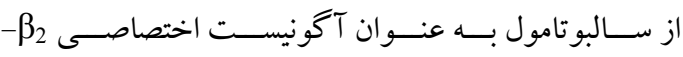
آدرنرزيك استفاده شد.

نتايج حاصل از مطالعات رفتـارى بـا استفاده از تسـت شـاتل

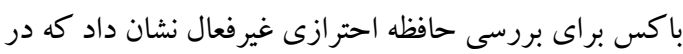

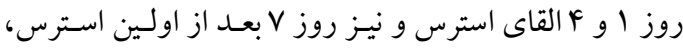

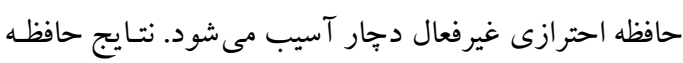
احترازى غيرفعال نشان داد كهه در حيوانات گحروه كنترل

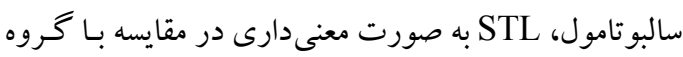
استرس افزايش يافته بـود. نتايج حافظه احترازى غير فعـال

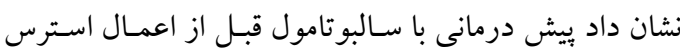

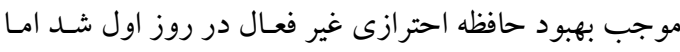

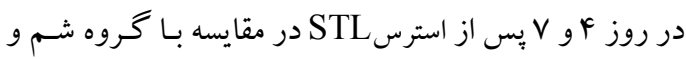
استرس افزايش نيافت، لذا موجب بهبود حافظه نشـد. نتـايج بررسى حافظه فضـايى در تسـت بـارنز نشـان داد كـه بـيش

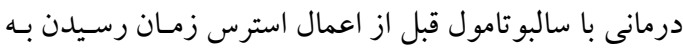

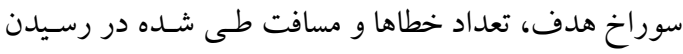

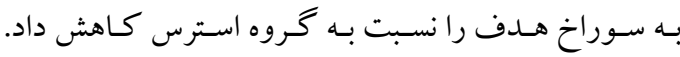

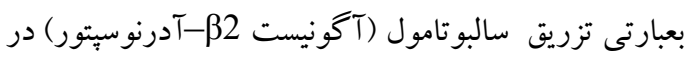
ناحيه BLA از تخريب حافظه فضايى و احترازى غيرفعال متعاقب استرس جلو گيرى كرده است. اسـترس مـزمن نـواحى مختلـف مغـزى را تحـت تـاثير قـرار

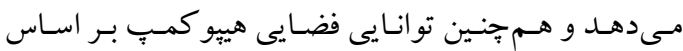

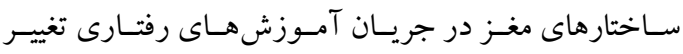


44

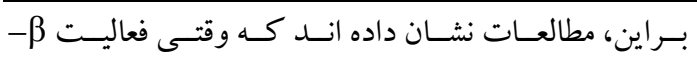

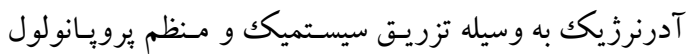
مهار مى شود، اثر افزايش هيجانى انخيزشى همانند اثر حافظه در آميخدال كاسته مىشود.

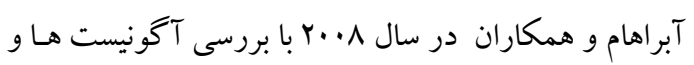

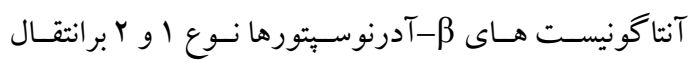

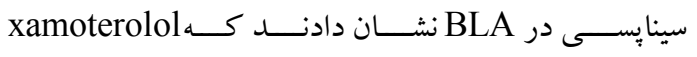

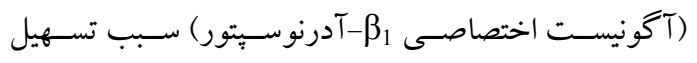
يتانسيل ميدانى سينايسى تحريكى در BLA مى مشود ولى در

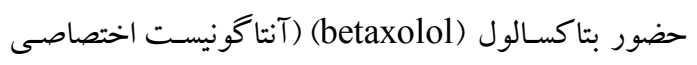

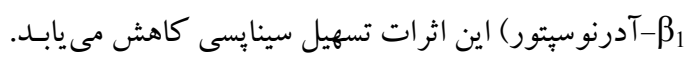

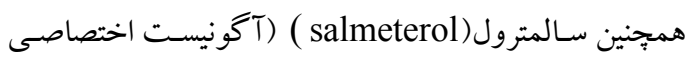

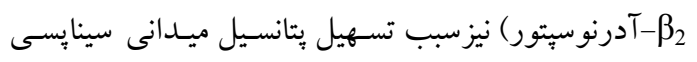

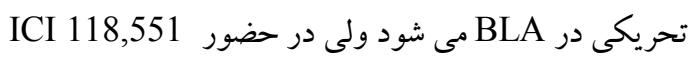
(آنتاكونيست اختصاصى

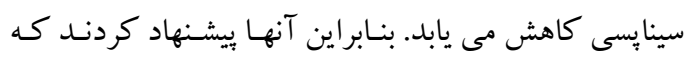

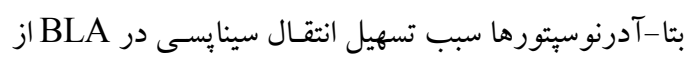

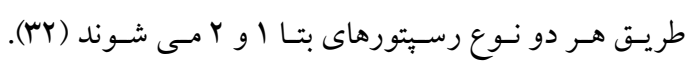

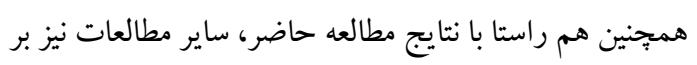

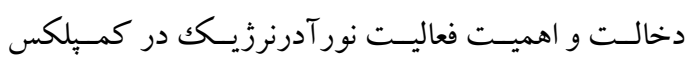
آميكدال و BLA بر تثبيت حافظه تاكيد دارند. علاوه بـراين

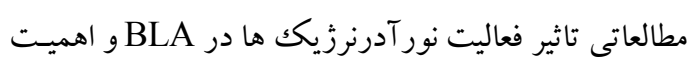

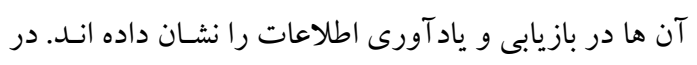

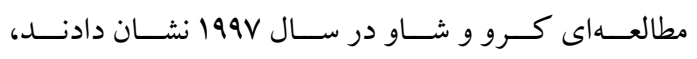

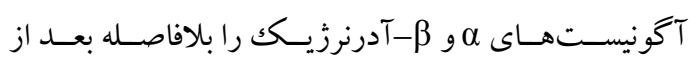

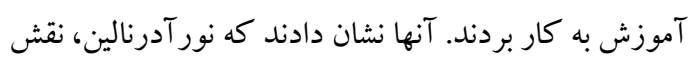

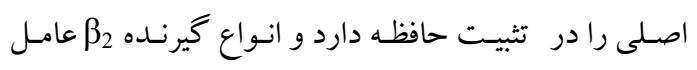
اصلى فـاز ميـانى در تشـكيل حافظه اسـت. بـه عـلاوه آنها

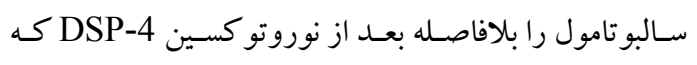

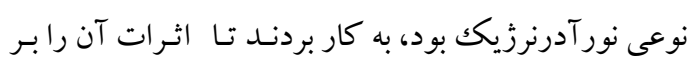
حافظه مورد سنجش قرار دهنـــ نور آدرنـالين و سـالبو تامول

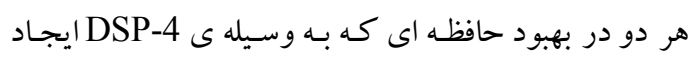

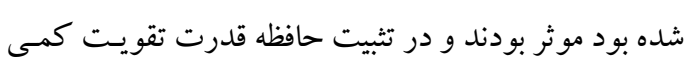

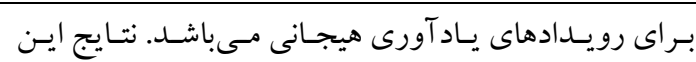

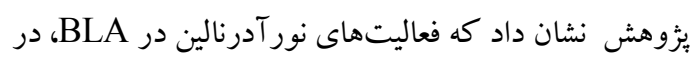

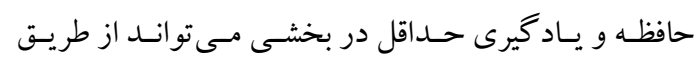
كيرندهاى

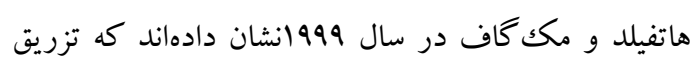
بعد از آموزش نورايىنفرين به BLA، ياد ئرى و و حافظه

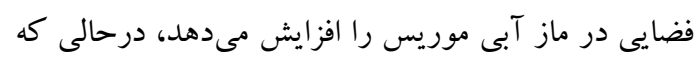

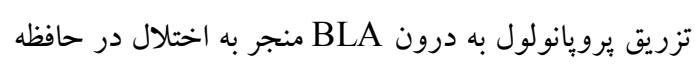
در اين تست مىشود (YV). همجنين فرى و مكك كاف درو

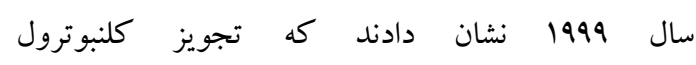
(Clenbuterol) به BLA سبب افزايش حافظه احترازى مىشود (YN). مطالعات نشان دادهاند كه ابىنفرين بر روى تثبيت حافظه از إز طريق فعاليت نور آدرنرزيك در آميكدال تاثيرمى گذارد.

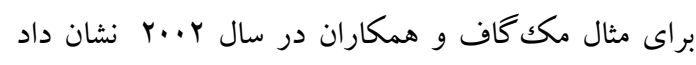
كه تزريق نورايى نفرين در BLA سبب افزايش و تثبيت

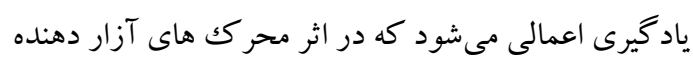

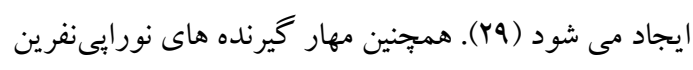

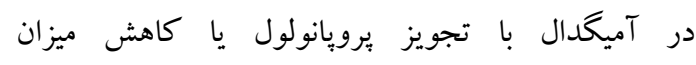
نورايىنفرين درآميگدال از طريق تزريق نوروتو كسين DSP-(N-2-chloroethyl-N-ethylbromobenzylamine)

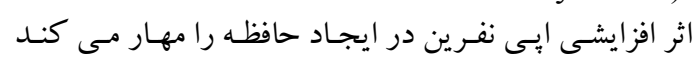

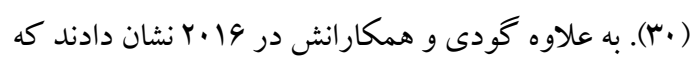
تزريـق برويـانولول بـه طـور مستقيم در BLA سـبب مهـار افزايش ترس در حافظه عادتى (memory habit) مى شـود.

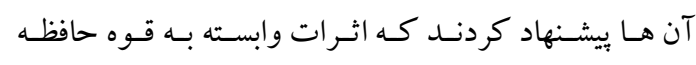

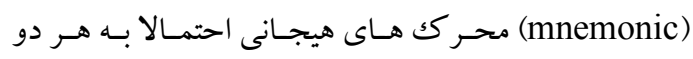

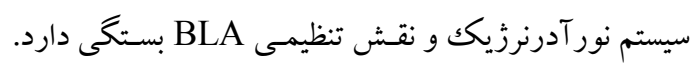

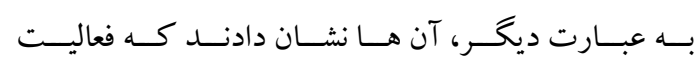

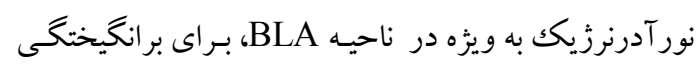

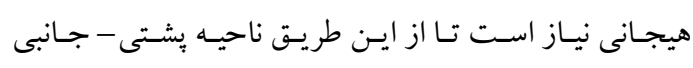

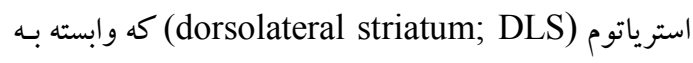
حافظه عـادتى اسـت را تحـت تـاثير قرار دهـــ (آم). عـلاوه 


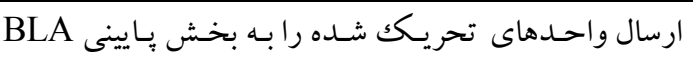

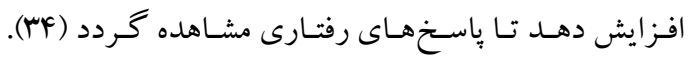

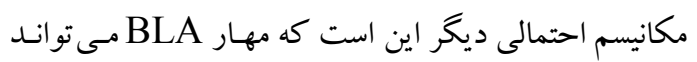

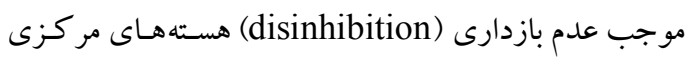

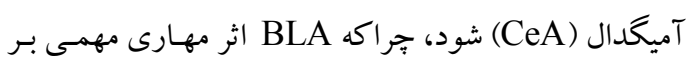

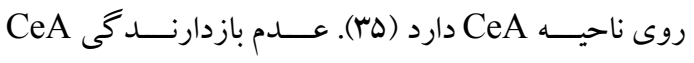

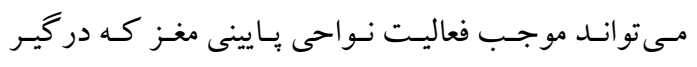

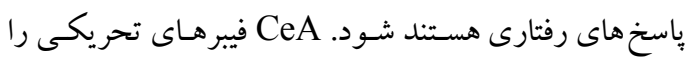

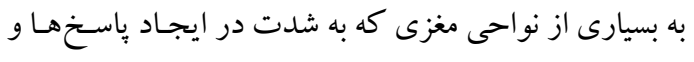

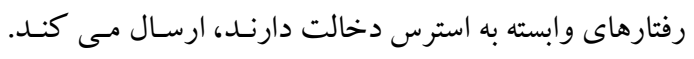

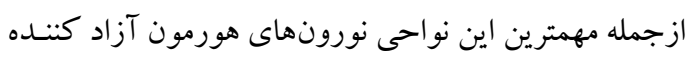

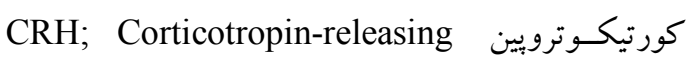
است كه ورودى هايى به لو كوس سـرولئوس (hormone)

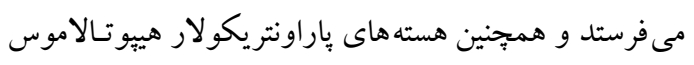
(PVN; Paraventricular nucleus)

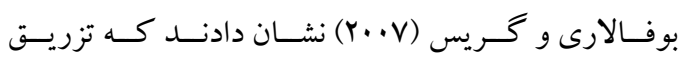

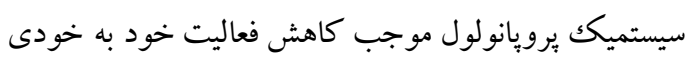
نـورونهـاى BLA مسىشـود (spontaneous activity)

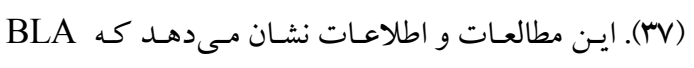
ازطريق ارسال بيام هايى به هييو كمبِ ممكن است در تعـديل

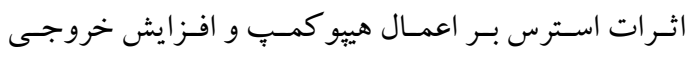

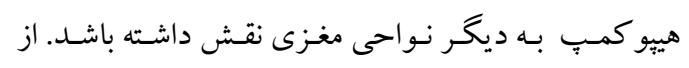

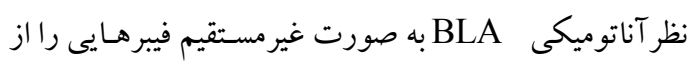
طريق كورتكس انتورينال به هييو كمبِ و به صورت مستئيم

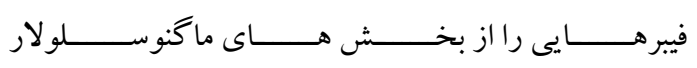

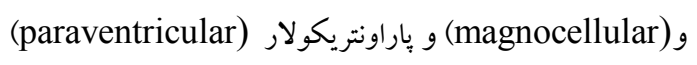

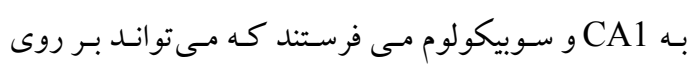
اعمال هييو كمب اثر بخذارد.

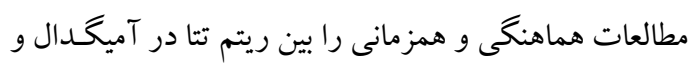

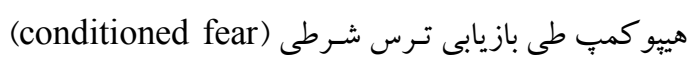

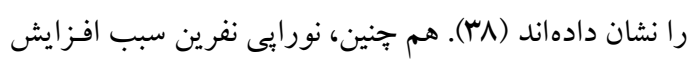

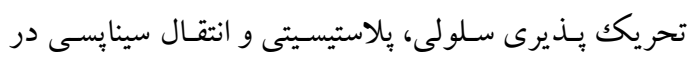

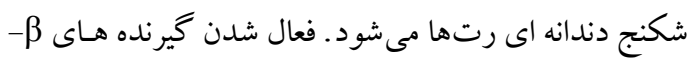

داشتند. آنهـا بيـان كردنـد كـه نقـش كلى نور آدرنـالين در تثبيت حافظه است، در حالى كه گيرنسه حافظه دخالت دارد (سr).

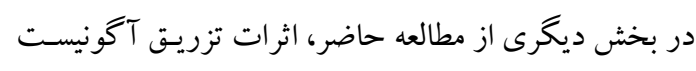

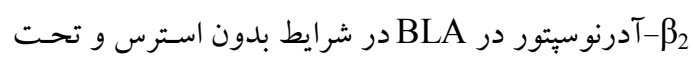

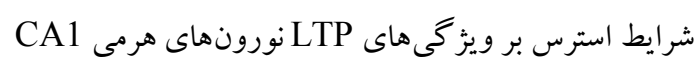

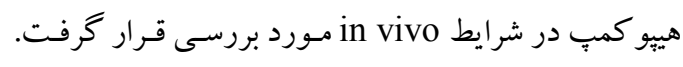

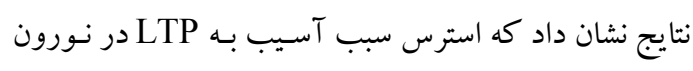

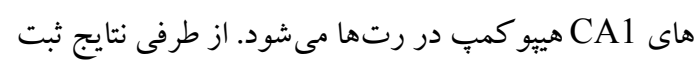

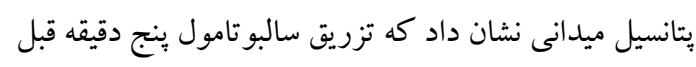

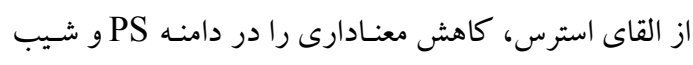
fEPSP درطول •ودقيقه بعسداز HFS در مقايسه بـا كروره هاى كنترل، شم و استرس ايجاد كرد.

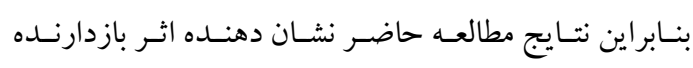

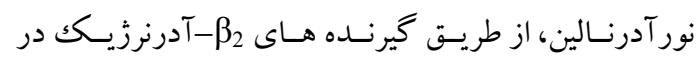

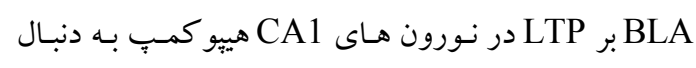

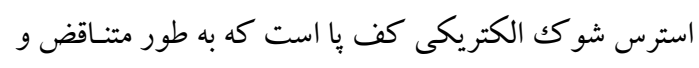

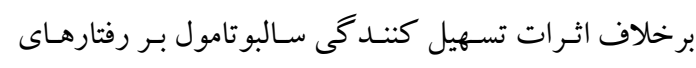
حافظه فضايى و هيجانى ديده شـده اسـت. بـه عبـارت ديخر

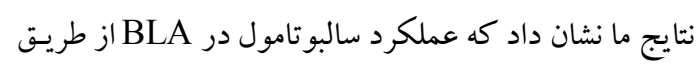

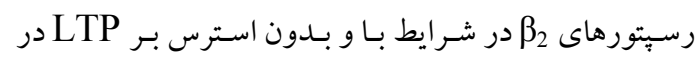
نورونهاى CA1 به صورت مهارى است.

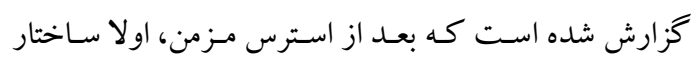

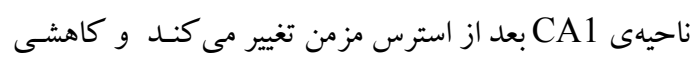

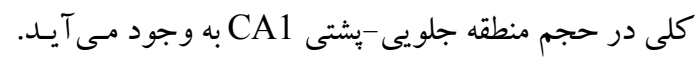

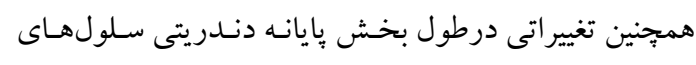

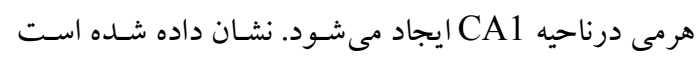

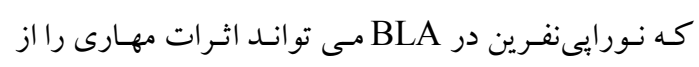

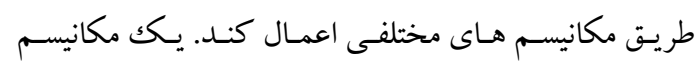

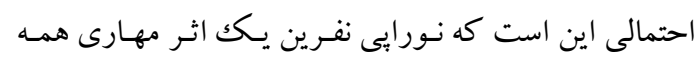

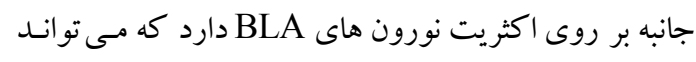
منجر به افزايش نسبت سيكنال به نسويز (signal-to-noise) واحدهايى كه تحريكك شده اند داشته باشد و ايـن مستو نواند 
4 اثرات تعديلى سالبوتاهول...

كه اسـترس شـو كَ الكتريكى كف بـ بـا بـه طور مكـرر در هييو كمٍ موجب آسيب حافظه شده كه ازطريق تحريكك

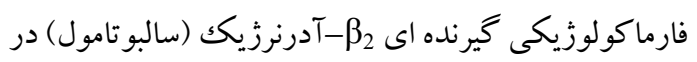
BLA اين آسيب بيشتر مى شود. عـلاوه بـراين بيشـتر شـدن فعاليت گيرنده هاى حافظه در هييو كمبِ را كاهش مسى دهـد. در توضسيح نتـايج

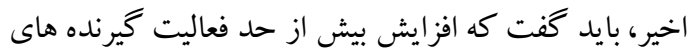

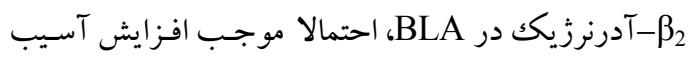

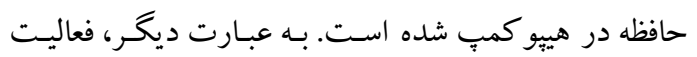
متوسط گيرنده هاى

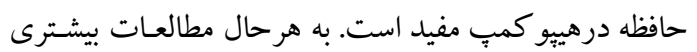

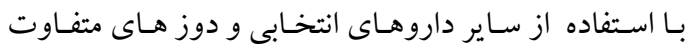

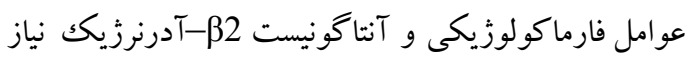

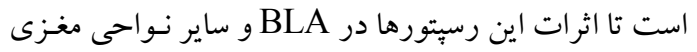
را بر انواع حافظه مشخص كرد.

\section{نتيجه تيرى}

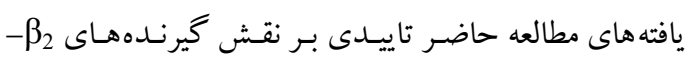

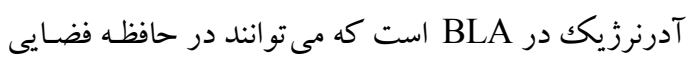

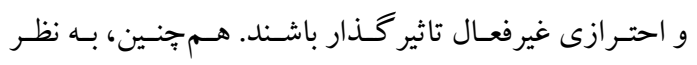

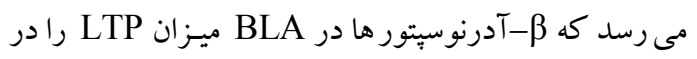

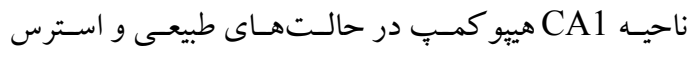

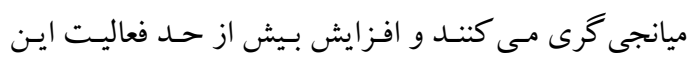

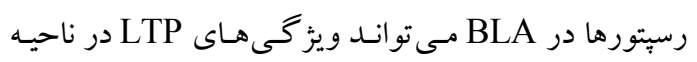

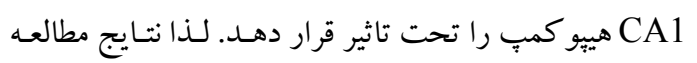

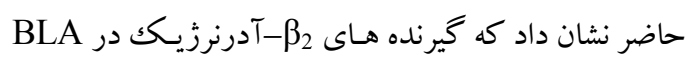

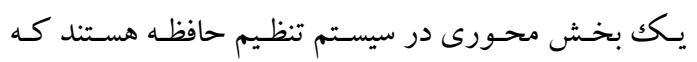

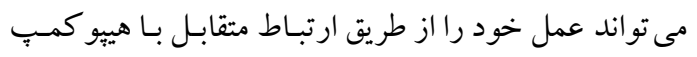

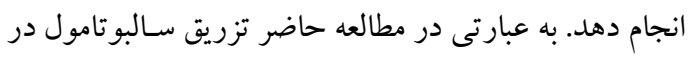

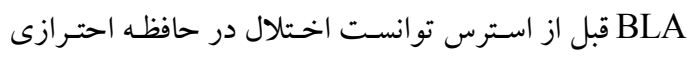

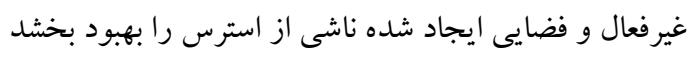

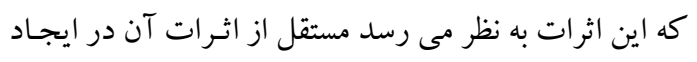
LTP در نورون هاى CA1 هييو كمبِ باشد.
آدرنرزيك مى تواند موجب تسهيل انتقال سينايسى شود، كه ته

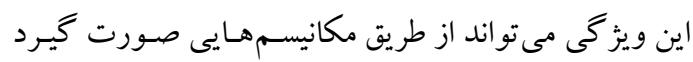

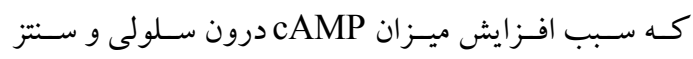
بروتئين جديد گردد و در نتيجه باعث كسب، تثبيت وحفظ إنظ

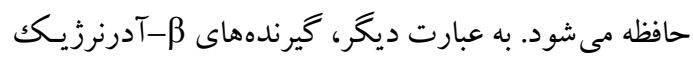

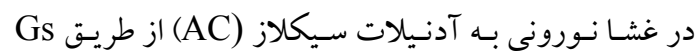

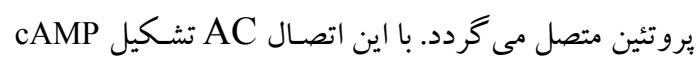

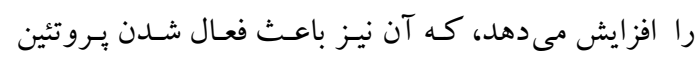

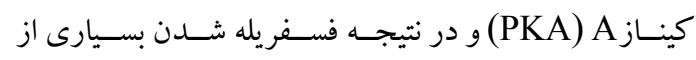

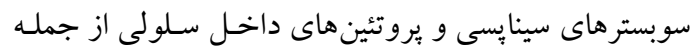
(response element binding protein) CREB

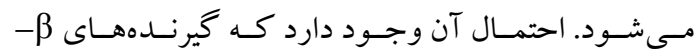

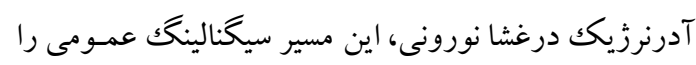

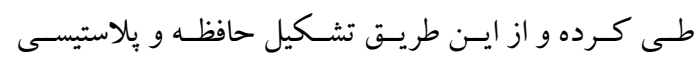

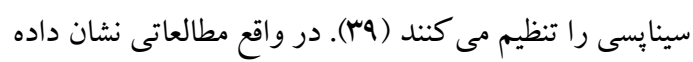

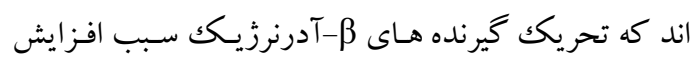

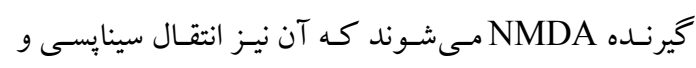

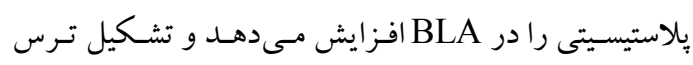

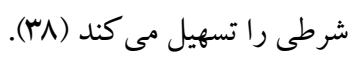
همان گونه كه در بالا ذكر شد، نتايج مطالعه حاضر نشان نشان داد كه تزريق دو سويه آكونيست اختصاصى گيرنسه هـای

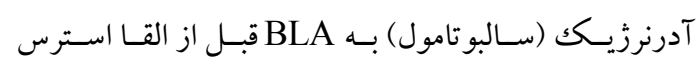

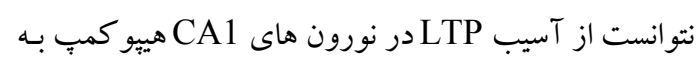

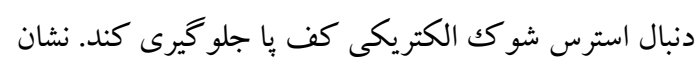

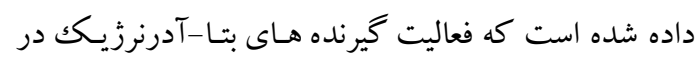

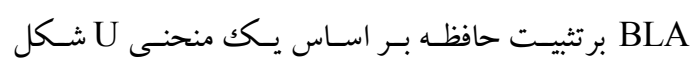
معكوس مى باشد. بدين صورت كه كه فعاليت بسيار كمى و

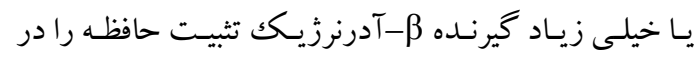

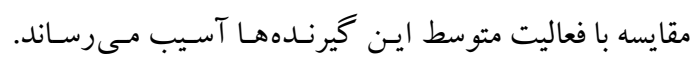

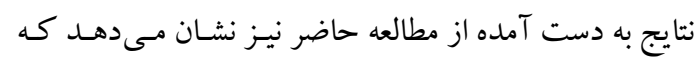

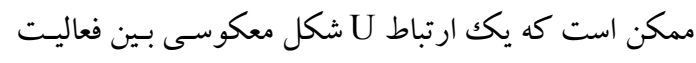
كيرنـده هـاى هاى CA1 با تكرار استرس وجود داشته باشد. بدين صورت 
1.Chovatiya R, Medzhitov R. Stress, inflammation, and defense of homeostasis. Mol Cell. 2014;54(2):281-8.

2.Godoy LD, Rossignoli MT, Delfino-Pereira P, Garcia-Cairasco N, de Lima Umeoka EH. A Comprehensive Overview on Stress Neurobiology: Basic Concepts and Clinical Implications. Front Behav Neurosci. 2018;12:1-23.

3.McIntyre CK, Roozendaal B. Adrenal stress hormones and enhanced memory. Neural Plasticity and Memory: From Genes to Brain Imaging (Bermudez-Rattoni, F. Ed.). CRC Press Boca Raton. 2007:267-8.

4.Ranjbar H, Aghaei I, Moosazadeh M, Shabani M. Angiotensin II type 1 receptor blocker losartan attenuates locomotor, anxiety-like behavior, and passive avoidance learning deficits in a sub-chronic stress model. Iran J Basic Med Sci. 2018;21(8):856.

5.Nazeri M, Shabani M, Ravandi SG, Aghaei I, Nozari M, Mazhari S. Psychological or physical prenatal stress differentially affects cognition behaviors. Physiol Beh. 2015;142:155-60.

6.McEwen BS, Bowles NP, Gray JD, Hill MN, Hunter RG, Karatsoreos IN, et al. Mechanisms of stress in the brain. Nat Neurosci. 2015;18(10):1353.

7.Ressler KJ. Amygdala activity, fear, and anxiety: modulation by stress. Biol Psychiatry. 2010;67(12):1117-9.

8.Wingenfeld K, Wolf OT. Stress, memory, and the hippocampus. Front Neurol Neurosci. 2014;34:109-20 .

9.Arnsten AF. Stress signalling pathways that impair prefrontal cortex structure and function. Nat Rev Neurosci. 2009;10:410-422

10.Hansen N. The longevity of hippocampus-dependent memory is orchestrated by the locus coeruleus-noradrenergic system. Neural Plast. 2017;2727602;1-10.

11.McCall JG, Siuda ER, Bhatti DL, Lawson LA, McElligott ZA, Stuber GD, et al. Locus coeruleus to basolateral amygdala noradrenergic projections promote anxiety-like behavior. Elife. 2017;6:e18247.

12Nathan SV, Griffith QK, Mcreynolds JR, Hahn EL, Roozendaal B. Basolateral amygdala interacts with other brain regions in regulating glucocorticoid effects on different memory functions. Ann N Y Acad Sci. 2004;1032(1):179-82.

13.de Voogd LD, Klumpers F, Fernández G, Hermans EJ. Intrinsic functional connectivity between amygdala and hippocampus during rest predicts enhanced memory under stress. Psychoneuroendocrinol. 2017;75:192-202.

14.Yang Y, Wang JZ. From Structure to Behavior in Basolateral Amygdala-Hippocampus Circuits. Front Neural Circuits. 2017;11:86.

15.Roozendaal B, McGaugh JL. Memory modulation. Behav Neurosci. 2011:125:797-824.

16. Vouimba RM, Richter-Levin G. Physiological dissociation in hippocampal subregions in response to amygdala stimulation. Cereb Cortex. 2005;15:1815-1821. 
اثرات تعديلى سالبوتاهول... Vo

17.LaLumiere RT, Buen TV, McGaugh JL. Post-training intra-basolateral amygdala infusions of norepinephrine enhance consolidation of memory for contextual fear conditioning. Neurosci. 2003;23:6754-6758.

18.Tully K, Bolshakov VY. Emotional enhancement of memory: how norepinephrine enables synaptic plasticity. Mol Brain. 2010;3:1-9.

Tully, K., Bolshakov, V.Y. Emotional enhancement of memory: how norepinephrine enables synaptic plasticity. Mol Brain 3, 15 (2010).

19.Ferry B, McGaugh JL. Involvement of basolateral amygdala $\alpha 2$-adrenoceptors in modulating consolidation of inhibitory avoidance memory. Learn Mem. 2008;154:238-243.

20.Valizadegan F, Oryan S, Nasehi M, Zarrindast MR. Interaction between Morphine and Noradrenergic System of Basolateral Amygdala on Anxiety and Memory in the Elevated Plusmaze Test Based on a Test-retest Paradigm. Arch Iran Med. 2013;16(5):281-287.

21.Ehteram BZ, Sahraei H, Meftahi GH, Khosravi M. Effect of intermittent feeding on gonadal function in male and female NMRI mice during chronic stress. Braz Arch Biol Technol. 2017;60:e170607.

22.Hassantash M, Sahraei H, Bahari Z, Meftahi GH, Vesali R. The role of dopamine D2 receptors in the amygdala in metabolic and behavioral responses to stress in male Swiss-Webster mice. Front Biology. 2017;12(4):298-310.

23.Mereu G, Fà M, Ferraro L, Cagiano R, Antonelli T, Tattoli M, et al. Prenatal exposure to a cannabinoid agonistproduces memory deficits linked to dysfunction inhippocampal long-term potentiation and glutamaterelease.Proc Natl Acad Sci USA. 2003;100(8):4915-20.

24.Conrad CD, Magariños AM, LeDoux JE, McEwen BS. Repeated restraint stress facilitates fear conditioning independently of causing hippocampal CA3 dendritic atrophy. Behav Neurosci. 1999;113(5):902-913.

25.Kim EJ, Pellman B, Kim JJ. Stress effects on the hippocampus: a critical review. Learn Mem. 2015;22(9):411-6.

26.Lindau M, Almkvist O, Mohammed AH. Effects of stress on learning and memory. InStress: Concepts, cognition, emotion, and behavior. Academic Press. 2016;153-160

27.Hatfield T, McGaugh JL. Norepinephrine infused into the basolateral amygdala posttraining enhances retention in a spatial water maze task. Neurobiol Learn Mem. 1999;71(2):232-9.

28.Ferry B, McGaugh JL. Clenbuterol administration into the basolateral amygdala post-training enhances retention in an inhibitory avoidance task. Neurobiol Learn Mem. 1999;72(1):8-12.

29.McGaugh JL, McIntyre CK, Power AE. Amygdala modulation of memory consolidation: interaction with other brain systems. Neurobiol Learn Mem. 2002;78(3):539-52.

30.Quirarte GL, Roozendaal B, McGaugh JL. Glucocorticoid enhancement of memory storage involves noradrenergic activation in the basolateral amygdala. Proc Natl Acad Sci U S A. 1997;94(25):14048-53.

31.Goode TD, Leong KC, Goodman J, Maren S, Packard MG. Enhancement of striatum-dependent memory by conditioned fear is mediated by beta-adrenergic receptors in the basolateral amygdala. Neurobiol Stress. 2016;3:74-82.

32.Abraham PA, Xing G, Zhang L, Eric ZY, Post R, Gamble EH, et al. $\beta 1$-and $\beta 2$-adrenoceptor induced synaptic facilitation in rat basolateral amygdala. Brain Res. 2008;1209:65-73.

33. Crowe SF, Shaw S. Salbutamol overcomes the effect of the noradrenergic neurotoxin DSP-4 on memory function in the day-old chick. Behav Pharmacol. 1997;8(2-3):216-22.

34.Devilbiss DM, Waterhouse BD. The effects of tonic locus ceruleus output on sensory-evoked responses of ventral posterior medial thalamic and barrel field cortical neurons in the awake rat. J Neurosci. 2004;24(48):10773-85.

35.Rosenkranz JA, Buffalari DM, Grace AA. Opposing influence of basolateral amygdala and footshock stimulation on neurons of the central amygdala. Biol Psychiatry. 2006;59:801-811.

36.Pitts MW, Todorovic C, Blank T, Takahashi LK. The central nucleus of the amygdala and corticotropin-releasing factor: insights into contextual fear memory. J Neurosci. 2009;29(22):7379-88. 
غ1 غلاهمسين sفتاهى

37.Buffalari DM, Grace AA. Noradrenergic modulation of basolateral amygdala neuronal activity: opposing influences of $\alpha-2$ and $\beta$ receptor activation. J Neurosci. 2007;27(45):12358-66.

38.Seidenbecher T, Laxmi TR, Stork O, Pape HC. Amygdalar and hippocampal theta rhythm synchronization during fear memory retrieval. Science. 2003;301(5634):846-50.

39.Qu LL, Guo NN, Li BM. $\beta_{1}$-and $\beta_{2}$-Adrenoceptors in basolateral nucleus of amygdala and their roles in consolidation of fear memory in rats. Hippocampus. 2008;18(11):1131-9. 